\title{
Perfil epidemiológico de la hepatitis B y D en Colombia
}

\author{
Carlos A Espinal ${ }^{1}$
}

\section{Resumen}

Colombia presenta una gran diversidad epidemiológica en las prevalencias de infección y portadores del virus $\mathrm{B}$ (VHB), de acuerdo con las regiones geográficas y sus grupos de población. El virus delta (VHD) se encuentra ampliamente distribuido, asociado con epidemias de hepatitis fulminante en áreas de elevada prevalencia del VHB.

Los resultados de los estudios realizados por instituciones y servicios de salud en grupos de población por regiones y departamentos, comunidades indígenas y trabajadores de salud, han permitido la configuración del mapa de riesgo para los virus $B$ y $D$, de acuerdo con los patrones de alta y mediana endemicidad de ambas infecciones en la población.

Las elevadas proporciones de infección informadas en comunidades, bancos de sangre y personal de salud, demuestran que Colombia es un país de alto riesgo para el VHB y $\mathrm{VHD}$, con niveles intermedios en algunos departamentos.

Las elevadas prevalencias en poblaciones indígenas requieren de un programa intensificado de control mediante la vacunación. Las coberturas de vacunación en la comunidad y en el personal de salud deben incrementarse con el fin de reducir la población susceptible y el riesgo de infección.

Colombia presenta tasas de riesgo intermedio para el hepatocarcinoma primario. Estudios en la ciudad de Cali confirman la asociación epidemiológica entre hepatocarcinoma, cirrosis y la prevalencia por comunas del VHB.

Estos factores ameritan la intensificación de la vacunación universal de la infancia y el inicio de programas de vacunación en los adolescentes. Adicionalmente, debe incrementarse la vacunación de los adultos a través de las diferentes entidades que desarrollan programas de prevención y promoción de la salud.

\section{Colombian hepatitis $B$ and $D$ epidemiological profile.}

The epidemiology of hepatitis $B$ infection in Colombia varies by geographic regions and population groups. Hepatitis B infection prevalence and incidence survey analysis carried out by research institutions and health services has determined the classification of high and intermediate endemicity regions in Colombia. High prevalences of infection and carrier rates have been reported from different geographic areas including the Amazon Basin, Orinoquia and the Atlantic and Pacific coastal regions.

High prevalences of delta virus infections and fulminant hepatitis outbreaks have been reported from these areas of high HBV endemicity.

${ }^{1}$ Director Científico, Biolehner

Recibido para su publicación: 8 de junio de 1998 - Aprobado para su publicación: 10 de septiembre de 1998 
Populations at high risk, including indian communities, require intensive infant vaccination programmes and age-expanded programmes to control and reduce the endemicity levels. Vaccination of adolescents should be recommended to effectively reduce the number of carriers and the incidence and prevalence of HBV amongst the susceptible population. Routine vaccination of adolescents should be considered at ages 11 to 12 years, before adolescents initiate high-risk practices.

More hepatitis B immunisation programmes for health workers should be implemented in hospitals and health-centers. Vaccination should be recommended as early as possible, as a requirement for school or higher education admission.

Colombia has reported intermediate rates for primary hepatocellular carcinoma. Surveys in Cali, Valle del Cauca, confirmed the epidemiological relationship between high risk urban and sub-urban areas for hepatitis B, hepatocellular carcinoma and cirrhosis.

La infección por el virus de la hepatitis B (VHB) es la causa infecciosa más importante de enfermedad hepática aguda y crónica del mundo y una de las primeras causas de carcinoma hepatocelular y cirrosis. La infección por el virus $B$ es considerada una infección universal en la infancia en la mayoría de los países que conforman el mundo en desarrollo. Se estima que esta pandemia ha infectado a más de 2.000 millones de personas, mantiene un reservorio de aproximadamente 300 a 400 millones de portadores crónicos del antígeno de superficie (Ags HB), anualmente ocasiona el fallecimiento de 1 a 2 millones de personas y 700.000 casos de cirrosis y es la primera causa de carcinoma hepatocelular en el mundo. Por estos motivos, el virus $B$ es considerado como el segundo agente carcinógeno en el humano después del cigarrillo (1 - 4).

Aproximadamente, $45 \%$ de la población mundial reside en áreas de alta endemicidad, con tasas que superan el $8 \%$ de portadores en la población general y cuyos mecanismos de transmisión más frecuentes son la infección perinatal y la transmisión horizontal. Cerca de 122 millones de niños nacen anualmente en áreas de alta y mediana endemicidad con un elevado riesgo de desarrollar estado de portador crónico (5).

En América Latina, el número de portadores del virus de la hepatitis $B$ se estima en 6,6 millones de individuos. Entre 6,6 y 12 millones de personas han sido infectadas por el virus $B$,
$65 \%$ de ellas residentes en Suramérica. De acuerdo con los cálculos de incidencia, anualmente pueden presentarse, por lo menos, 8.000-15.000 nuevos portadores crónicos y 4.000 casos de enfermedad hepática crónica. Adicionalmente, se esperan anualmente 60.000 casos de cirrosis y 3.000 casos de hepatocarcinoma (6).

El virus delta (VHD) requiere de la asociación con el VHB para replicarse y su infección puede manifestarse como una coinfección o como una sobreinfección en portadores crónicos del AgsHB. Los individuos con coinfección tienen una mayor probabilidad de desarrollar hepatitis fulminante, a diferencia de los que contraen una sobreinfección con el virus delta, quienes en un $70-80 \%$ desarrollan enfermedad hepática crónica con cirrosis, comparados con $15-30 \%$ de pacientes con enfermedad crónica ocasionada solamente por el virus $B$. Se estima que, por lo menos, 300.000 personas en Suramérica están infectadas por el VHD (6).

La clínica, la epidemiología y la patología de la hepatitis delta en Colombia han sido extensamente descritas por B.Buitrago y col. del Instituto Nacional de Salud (7 - 11).

Con el fin de describir la epidemiología de las hepatitis B y D y elaborar un mapa de riesgo por niveles de endemicidad en Colombia, se presenta una revisión de los estudios realizados por diferentes investigadores, instituciones y servicios de salud en poblaciones, poblaciones indígenas y personal de salud. 


\section{Métodos}

\section{Base de datos}

La revisión se realizó con base en los artículos publicados sobre la epidemiología de las hepatitis B y $D$, información no publicada pero analizada por los autores referenciados y sus respectivas instituciones, informes y boletines técnicos de los servicios de salud y del Ministerio de Salud, e informes sobre las comunidades indígenas (algunos publicados) cedidos por el Grupo de Epidemiología del Instituto Nacional de Salud y los investigadores de la Expedición Humana de la Universidad Javeriana.

Con la información recopilada, se creó una base de datos dividida por regiones y departamentos, de acuerdo con la clasificación geográfica presentada en el Informe Quincenal Epidemiológico Nacional (IQEN), Sistema Alerta Acción, publicado por la Dirección General de Promoción y Prevención del Ministerio de Salud y la Subdirección de Epidemiología y Laboratorio Nacional de Referencia del Instituto Nacional de Salud (INS).

\section{Grupos de análisis}

A su vez, la información obtenida se ha organizado bajo los siguientes grupos de análisis:

- Estudios en poblaciones, en los cuales se describen los hallazgos más relevantes de las prevalencias de portadores e infección, globales y por grupo de edad en municipios, localidades o por departamentos.

- Grupos especiales como pacientes en hemodiálisis, con hemofilia y con hepatopatías agudas o crónicas.

- Prevalencia de AgsHB y anticuerpos contra el antígeno central (Antic-HB) en bancos de sangre, con el objeto de conocer información en regiones o departamentos donde no se han realizado estudios en población. La información obtenida en bancos de sangre está definida para población mayor de 18 años de edad.

- Información en comunidades indígenas sobre tasas de portadores y de infección.
- Estudios realizados en el personal de salud sobre prevalencias de portadores y de infección, globales y por especialidades.

En algunos estudios, las prevalencias de infección se ajustaron con base en la sumatoria de los marcadores positivos en la población estudiada, de acuerdo con la definición establecida en la gran mayoría de los estudios analizados. Los portadores se analizaron como la proporción de individuos con AgsHB positivo, descrito en todos los estudios revisados.

Los criterios que permitieron la clasificación de los departamentos en alto y mediano riesgo se basan en las tasas de infección y de portadores del VHB establecidas por la OMS (12). Adicionalmente se consideró la presencia simultánea de los virus de las hepatitis B y Delta, registrados por estudios de prevalencia o reportes confirmados de casos y brotes de hepatitis fulminante asociados con el VHD.

\section{Resultados}

Los resultados de los estudios en poblaciones por regiones y departamentos pueden observarse en los cuadros 1-11. Las prevalencias en bancos de sangre aportan información complementaria para los Departamentos que no presentan estudios en poblaciones específicas (cuadro 12) y corroboran la información obtenida en los grupos de población. Los cuadros 13 y 14 resumen las prevalencias de infección y portadores del AgsHB en comunidades indígenas por etnias y departamentos. Los resultados sobre estudios en el personal de la salud se resumen en los cuadros 15-20.

Las referencias específicas de cada autor han sido secuencialmente numeradas desde la número 13 hasta la número 99 y se han incluido en los respectivos cuadros que describen los principales hallazgos de cada uno de los investigadores.

El análisis y clasificación de riesgo se presenta por regiones y departamentos e incluye, para cada uno de ellos, los resultados obtenidos en las variables de población (general, bancos de sangre, comunidades indígenas y sector salud). 
Cuadro 1. ESTUDIOS POBLACIONALES DE HEPATITIS B Estudios por Regiones / Departamentos.

\begin{tabular}{|c|c|c|c|c|c|}
\hline 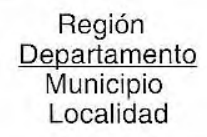 & $\begin{array}{c}\text { Autor o } \\
\text { Referencia } \\
\text { Institución }\end{array}$ & $\begin{array}{l}\text { Grupo de } \\
\text { Población } \\
\text { n individuos }\end{array}$ & $\begin{array}{c}\text { Prevalencia } \\
\text { Infección } \\
\%\end{array}$ & $\begin{array}{c}\text { Prevalencia } \\
\text { Portadores } \\
\% \\
\text { AgsHB }\end{array}$ & $\begin{array}{l}\text { Virus Delta } \\
\quad(\text { VHD })\end{array}$ \\
\hline \multicolumn{6}{|c|}{ AMAZONIA ORINOQUIA } \\
\hline 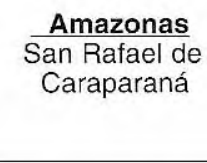 & $\begin{array}{l}\text { M. Martínez } \\
\text { INS } \\
(14)\end{array}$ & $\begin{array}{c}\text { Indígenas } \\
\text { Huitotos } \\
n=404\end{array}$ & $\begin{array}{c}\text { Global: } 66 \% \\
\text { 0-9 a: } 49 \% \\
\text { 10 a: } 71 \% \\
\text { Mujeres: } 61 \%\end{array}$ & $\begin{array}{c}18 \% \\
0-9 \text { a: } 15 \% \\
>10 \text { a: } 18 \%\end{array}$ & $\begin{array}{c}+ \\
\text { Casos de } \\
\text { Hepatitis } \\
\text { Fulminante } \\
(\mathrm{HF})\end{array}$ \\
\hline $\begin{array}{l}\text { Ribera ríos } \\
\text { Putumayo } \\
\text { Caraparaná }\end{array}$ & $\begin{array}{l}\text { M. Martínez } \\
\text { INS } \\
(15)\end{array}$ & $\begin{array}{c}\text { Poblaciones } \\
\text { ribereñas } \\
n=1113 \\
(>4 \text { años })\end{array}$ & $\begin{array}{c}\text { Global: } 78 \% \\
\text { Población ribereña } \\
88 \% \\
\text { Otras: } 68 \%\end{array}$ & $12 \%$ & N.R \\
\hline $\begin{array}{l}\text { El Encanto } \\
\text { Río Caquetá }\end{array}$ & $\begin{array}{l}\text { B. Buitrago } \\
\text { (M. Martínez) } \\
\text { INS } \\
(16)\end{array}$ & $\begin{array}{c}\text { Indígenas } \\
\text { Huitotos } \\
n=454 \\
(0-59 \text { años })\end{array}$ & $\begin{array}{l}\text { Global: } 69 \% \\
\text { 0-4 a: } 50 \% \\
5-9 \text { a: } 64 \% \\
10-44 \text { a: } 71 \% \\
>45 \text { a: } 33 \%\end{array}$ & $\begin{array}{c}22 \% \\
15-44 \text { a: } 29 \%\end{array}$ & Casos de HF $^{+}$ \\
\hline $\begin{array}{l}\text { San Rafael de } \\
\text { Caraparaná }\end{array}$ & $\begin{array}{c}\text { F. de la } \mathrm{Hoz} \\
\text { INS } \\
(17)\end{array}$ & $\begin{array}{l}\text { Indígenas } \\
\text { Huitotos } \\
n=198 \\
(8-15 \text { años })\end{array}$ & $\begin{array}{l}\text { Global: } 61 \% \\
11-12 \text { a: } 56 \% \\
13-15 \text { a: } 73 \%\end{array}$ & N.R & ${ }_{\text {Casos de H F }}^{+}$ \\
\hline \multirow{2}{*}{$\begin{array}{c}\text { Puerto } \\
\text { Santander } \\
\text { Puerto Nariño } \\
\text { Puerto Arica } \\
\text { Tarapacá } \\
\text { Chorrera }\end{array}$} & $\begin{array}{l}\text { L.M. } \\
\text { Cristancho }\end{array}$ & \multirow{2}{*}{$\begin{array}{c}81 \% \\
\text { Indígenas } \\
19 \% \\
\text { Mestizos } \\
n=1,500 \\
>5 \text { años }\end{array}$} & $\begin{array}{c}\text { Global: } 74,9 \% \\
\text { M: } 73,6 \% \\
\text { H: } 76,2 \%\end{array}$ & $10,7 \%$ & N.R \\
\hline & $\begin{array}{c}\text { Servicio de } \\
\text { Salud del } \\
\text { Amazonas } \\
(18)\end{array}$ & & \multicolumn{3}{|c|}{$\begin{array}{l}\text { Prevalencia de infección por edades } \\
5 \text { a: } 11 \% \\
6-9 \text { a: } 32 \% \\
10-14 \text { a: } 80 \% \\
15-44 \text { a: } 87 \% \\
\text { > } 45 \text { a: } 94 \% \\
\text { Indígenas: } 78,8 \% \text { Mestizos: } 71,2 \% \\
\text { Blancos: } 52,6 \%\end{array}$} \\
\hline $\begin{array}{l}\text { Tasas para el } \\
\text { Departamento }\end{array}$ & $\begin{array}{l}\text { Servicio de } \\
\text { Salud del } \\
\text { Amazonas } \\
(19)\end{array}$ & $\begin{array}{l}\text { 1985-93: } \\
14 \text { casos HF } \\
15 \text { de cirrosis } \\
4 \text { de HPC }\end{array}$ & $\begin{array}{c}\text { Global: } 75 \% \\
\text { Tasa } 1995 \\
34,7 \times 100.000 \text { hab }\end{array}$ & $\begin{array}{c}8,5 \% \\
\text { Donantes de } \\
\text { sangre } \\
1989-94: \\
3,2-4,9 \%\end{array}$ & $\stackrel{+}{\text { Casos de HF }}$ \\
\hline
\end{tabular}

Cuadro 2. ESTUDIOS POBLACIONALES DE HEPATITIS B Estudios por Regiones / Departamentos.

\begin{tabular}{cccccc}
\hline $\begin{array}{c}\text { Región } \\
\text { Departamento } \\
\begin{array}{c}\text { Municipio } \\
\text { Localidad }\end{array}\end{array}$ & $\begin{array}{c}\text { Autor o } \\
\text { Referencia } \\
\text { Institución }\end{array}$ & $\begin{array}{c}\text { Grupo de } \\
\text { Población } \\
\text { n individuos }\end{array}$ & $\begin{array}{c}\text { Prevalencia } \\
\text { Infección } \\
\%\end{array}$ & $\begin{array}{c}\text { Prevalencia } \\
\text { Portadores } \\
\%\end{array}$ & $\begin{array}{c}\text { Virus Delta } \\
\text { AgsHB }\end{array}$ \\
\hline $\begin{array}{c}\text { Guaviare } \\
\text { Charras }\end{array}$ & $\begin{array}{c}\text { F. Rivas } \\
\text { INS } \\
(20,21)\end{array}$ & $\begin{array}{c}\text { Población } \\
n=84\end{array}$ & Global: $51,2 \%$ & $13,1 \%$ & + \\
\hline
\end{tabular}


Continuación Cuadro 2.

\begin{tabular}{|c|c|c|c|c|c|}
\hline $\begin{array}{l}\text { Región } \\
\text { Departamento } \\
\text { Municipio } \\
\text { Localidad }\end{array}$ & $\begin{array}{c}\text { Autor o } \\
\text { Referencia } \\
\text { Institución }\end{array}$ & $\begin{array}{l}\text { Grupo de } \\
\text { Población } \\
n \text { individuos }\end{array}$ & $\begin{array}{c}\text { Prevalencia } \\
\text { Infección } \\
\%\end{array}$ & $\begin{array}{c}\text { Prevalencia } \\
\text { Portadores } \\
\% \\
\text { AgsHB }\end{array}$ & $\begin{array}{c}\text { Virus Delta } \\
(\mathrm{VHD})\end{array}$ \\
\hline $\begin{array}{c}\text { Guainía } \\
\text { Puerto } \\
\text { Esperanza }\end{array}$ & $\begin{array}{c}\text { B. Buitrago } \\
\text { (M. Martínez ) } \\
\text { INS } \\
(16)\end{array}$ & $\begin{array}{c}\text { Indígenas } \\
\text { Guahibo } \\
n=105\end{array}$ & $\begin{array}{c}\text { Global: } 67,6 \% \\
<14 \text { a: } 36 \%\end{array}$ & N.R & $\begin{array}{c}{ }_{\text {Caso índice }}^{+} \\
\mathrm{HF}\end{array}$ \\
\hline$\frac{\text { Putumayo }}{\text { Puerto }}$ & $\begin{array}{l}\text { S. Rondón } \\
\text { Hospital }\end{array}$ & $\begin{array}{l}\text { Habitantes y } \\
\text { personal del }\end{array}$ & Global: $40,8 \%$ & $\begin{array}{r}7,0 \% \\
M: 8,0 \% \\
\end{array}$ & N.R \\
\hline $\begin{array}{c}\text { Leguízamo } \\
\text { La Tagua } \\
\text { Batallón }\end{array}$ & $\begin{array}{l}\text { Naval } \\
(22)\end{array}$ & $\begin{array}{l}\text { Batallón } \\
n=230\end{array}$ & $\begin{array}{l}\text { Por localidades: } \\
\text { P. Leguízamo: } 38 \% \\
\text { La Tagua: } 56 \% \\
\text { Batallón: } 40 \% \\
\text { Mujeres: } 42 \%\end{array}$ & $\begin{array}{c}\text { Localidades } \\
\text { P. Leguízamo: } \\
4,5 \% \\
\text { La Tagua: } \\
15 \% \\
\text { Batallón: } \\
5,0 \%\end{array}$ & \\
\hline $\begin{array}{l}\text { Vaupés } \\
\text { Los Cerros }\end{array}$ & $\begin{array}{c}\text { B. Buitrago } \\
\text { ( M. Martínez ) } \\
\text { INS } \\
(23)\end{array}$ & $\begin{array}{l}\text { Indígenas } \\
\text { Cubeos } \\
\text { Personal de } \\
\text { salud } \\
n=152\end{array}$ & $\begin{array}{r}\text { Global: } 50 \% \\
\text { H: } 53,7 \% \\
\text { M: } 47,1 \% \\
<5 \text { a: } 26 \% \\
5-9 \text { a: } 43 \% \\
10-14 \text { a: } 62 \% \\
\text { > } 15 \text { a: } 61 \% \\
\text { 35-44 a: } 80 \%\end{array}$ & $\begin{array}{c}6,0 \% \\
\text { H: } 4,5 \% \\
\text { M: } 3,5 \% \\
\text { Por edades } \\
<5 \text { a: } 5,3 \% \\
15-24 \text { a: } 8,0 \% \\
35-44 \text { a: } 6,7 \%\end{array}$ & $\begin{array}{c}4,5 \% \\
\text { ( Anti-VHD) } \\
\text { H: } 7,0 \% \\
\text { M: } 2,0 \% \\
<4 \text { a: } 33 \% \\
<9 \text { a: } 12,5 \% \\
\text { H< }<\text { a: } 18 \%\end{array}$ \\
\hline \multicolumn{6}{|c|}{ CENTRO ORIENTE } \\
\hline \multirow{3}{*}{$\begin{array}{c}\begin{array}{c}\text { Santafé de } \\
\text { Bogotá }\end{array} \\
(24)\end{array}$} & $\begin{array}{l}\text { B. Buitrago } \\
\text { (M. Guzmán ) } \\
\text { INS }\end{array}$ & $\begin{array}{c}\text { Maternas } \\
\text { H. M. Infantil } \\
n=68\end{array}$ & N.R & $4,4 \%$ & N.R \\
\hline & & $\begin{array}{l}\text { Recién } \\
\text { nacidos } \\
68\end{array}$ & N.R & $2,9 \%$ & N.R \\
\hline & $\begin{array}{l}\text { Sanmiguel A } \\
\text { Colegio } \\
\text { Mayor del } \\
\text { Rosario ( } 25 \text { ) }\end{array}$ & $\begin{array}{c}\text { Maternas } \\
\text { H.U.L.V.S } \\
n=200\end{array}$ & N.R & $1,0 \%$ & N.R \\
\hline
\end{tabular}

Cuadro 3. ESTUDIOS POBLACIONALES DE HEPATITIS B Estudios por Regiones / Departamentos.

\begin{tabular}{cccccc}
\hline $\begin{array}{c}\text { Región } \\
\text { Departamento } \\
\text { Municipio } \\
\text { Localidad }\end{array}$ & $\begin{array}{c}\text { Autor o } \\
\text { Referencia } \\
\text { Institución }\end{array}$ & $\begin{array}{c}\text { Grupo de } \\
\text { Población } \\
\text { nindividuos }\end{array}$ & $\begin{array}{c}\text { Prevalencia } \\
\text { Infección } \\
\%\end{array}$ & $\begin{array}{c}\text { Prevalencia } \\
\text { Portadores } \\
\% \\
\text { AgsHB }\end{array}$ & $\begin{array}{c}\text { Virus Delta } \\
\text { (VHD) }\end{array}$ \\
\hline $\begin{array}{c}\text { F. Sierra } \\
\text { Instituto } \\
\text { Materno } \\
\text { Infantil } \\
\text { HSJD (26) }\end{array}$ & $\begin{array}{c}\text { Maternas } \\
n=175 \\
\text { Recién } \\
\text { nacidos } \\
175\end{array}$ & N.R & $9,5 \%$ & N.R \\
\hline
\end{tabular}


Continuación Cuadro 3.

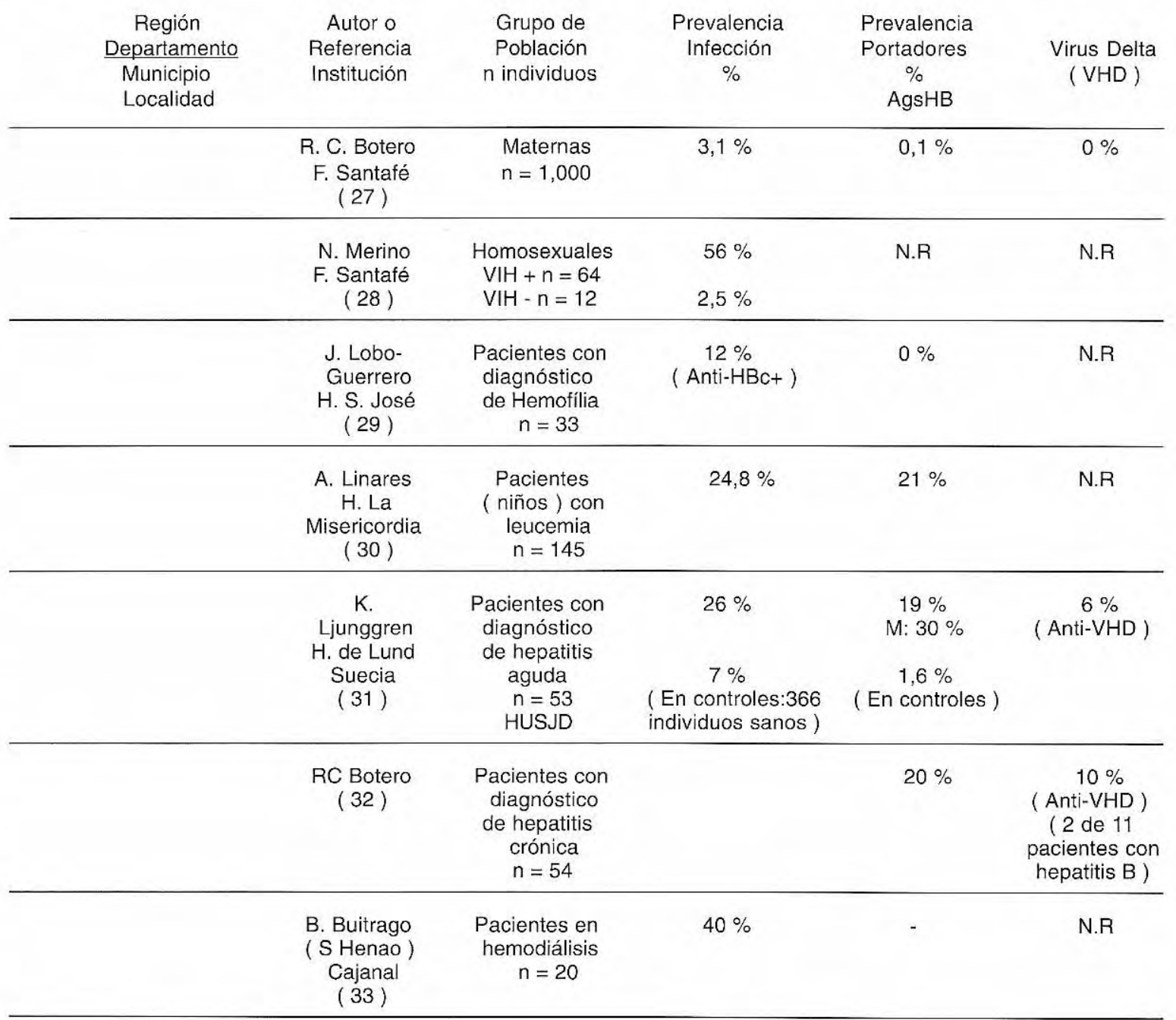

Cuadro 4. ESTUDIOS POBLACIONALES DE HEPATITIS B Estudios por Regiones / Departamentos.

\begin{tabular}{|c|c|c|c|c|c|}
\hline $\begin{array}{l}\begin{array}{c}\text { Región } \\
\text { Departamento }\end{array} \\
\text { Municipio } \\
\text { Localidad }\end{array}$ & $\begin{array}{l}\text { Autor o } \\
\text { Referencia } \\
\text { Institución }\end{array}$ & $\begin{array}{c}\text { Grupo de } \\
\text { Población } \\
\text { n individuos }\end{array}$ & $\begin{array}{c}\text { Prevalencia } \\
\text { Infección } \\
\%\end{array}$ & $\begin{array}{c}\text { Prevalencia } \\
\text { Portadores } \\
\% \\
\text { AgsHB }\end{array}$ & $\begin{array}{c}\text { Virus Delta } \\
\text { (VHD) }\end{array}$ \\
\hline & $\begin{array}{c}\text { H Cuevas } \\
\text { INS } \\
(34)\end{array}$ & $\begin{array}{l}\text { Muestras de } \\
\text { sangre para } \\
\text { diagnóstico } \\
\quad n=232 \\
\text { Enero-Marzo } \\
1996\end{array}$ & $\begin{array}{c}\text { Global: } 31,3 \% \\
\text { Córdoba: } 28,5 \% \\
\text { La Guajira: } 21,5 \% \\
\text { Quindío: } 31,5 \% \\
\text { Guaviare: } 70,5 \%\end{array}$ & $\begin{array}{r}\text { Global: } 9,6 \% \\
\begin{array}{r}14,2 \% \\
2,0 \% \\
10,5 \% \\
47 \%\end{array}\end{array}$ & N.R \\
\hline
\end{tabular}


Continuación Cuadro 4.

\begin{tabular}{|c|c|c|c|c|c|}
\hline $\begin{array}{c}\begin{array}{c}\text { Región } \\
\text { Departamento }\end{array} \\
\text { Municipio } \\
\text { Localidad }\end{array}$ & $\begin{array}{l}\text { Autor o } \\
\text { Referencia } \\
\text { Institución }\end{array}$ & $\begin{array}{c}\text { Grupo de } \\
\text { Población } \\
\text { n individuos }\end{array}$ & $\begin{array}{c}\text { Prevalencia } \\
\text { Infección } \\
\%\end{array}$ & $\begin{array}{c}\text { Prevalencia } \\
\text { Portadores } \\
\% \\
\text { AgsHB }\end{array}$ & $\begin{array}{c}\text { Virus Delta } \\
\text { (VHD) }\end{array}$ \\
\hline
\end{tabular}

\begin{tabular}{|c|c|c|c|c|c|}
\hline$\frac{\text { Cundinamarca }}{\text { Tocaima }}$ & $\begin{array}{l}\text { B. Buitrago } \\
\text { ( M. Guzmán ) } \\
\text { INS } \\
\text { ( } 35 \text { ) }\end{array}$ & $\begin{array}{c}\text { Pacientes con } \\
\text { lepra } \\
n=144\end{array}$ & N.R & $1,3 \%$ & N.R \\
\hline Utica & ( 35$)$ & $n=264$ & N.R & $0,3 \%$ & N.R \\
\hline Nariño & $\begin{array}{l}\text { L H Rubio } \\
\text { SS Salud } \\
\qquad(36)\end{array}$ & $\begin{array}{l}\text { Pacientes con } \\
\text { diagnóstico } \\
\text { de hepatitis } \\
\text { crónica } \\
n=26\end{array}$ & $\begin{array}{c}100 \% \\
\text { ( Prevalencia en } \\
\text { población: } 2,3 \% \text { ) }\end{array}$ & $40 \%$ & N.R \\
\hline La Vega & $\begin{array}{c}\text { M J Díaz } \\
\text { I. Virología } \\
\text { E.C Medicina } \\
\text { ( } 37 \text { ) }\end{array}$ & $\begin{array}{l}\text { Pacientes } \\
\text { diagnóstico } \\
\text { de hepatitis } \\
\text { crónica } \\
n=54\end{array}$ & $15 \%$ & N.R & N.R \\
\hline$\frac{\text { Tolima }}{\text { Honda }}$ & $\begin{array}{c}\text { F. de la Hoz } \\
\text { INS } \\
(38)\end{array}$ & $\begin{array}{c}\text { Mujeres en } \\
\text { consulta } \\
\text { Hospital } \\
n=246\end{array}$ & $13 \%$ & $4,0 \%$ & N.R \\
\hline Honda & $\begin{array}{l}\text { M. Velandia } \\
\text { INS } \\
\text { ( } 39 \text { ) }\end{array}$ & $\begin{array}{l}\text { Internos } \\
\text { cárcel } \\
n=103 \\
\text { Personal } \\
n=31\end{array}$ & $\begin{array}{l}\text { Global: } 33,6 \% \\
\text { Reclusos: } 39 \% \\
\text { Personal: } 12 \%\end{array}$ & $22 \%$ & N.R \\
\hline $\begin{array}{l}\text { Norte de } \\
\text { Santander } \\
\text { La Gabarra } \\
\text { Río de Oro } \\
\text { Tibú }\end{array}$ & $\begin{array}{l}\text { B. Buitrago } \\
\text { ( M. Martínez ) } \\
\text { INS } \\
(40)\end{array}$ & $\begin{array}{l}\text { Indígenas } \\
\text { Etnia Bari } \\
n=231 \\
\text { ( Mayores de } \\
5 \text { años ) }\end{array}$ & $\begin{array}{c}\text { Global: } 93 \% \\
\text { H: } 95 \% \\
\text { M: } 90 \%\end{array}$ & $\begin{array}{c}53 \% \\
\text { M: } 54 \% \\
\text { 5-14 años: } \\
59 \% \\
>15 \text { años: }\end{array}$ & $\begin{array}{c}3,5 \% \\
\text { ( Anti-VHD ) } \\
\text { H:5 \% M:2 \% } \\
5-14 \text { a: } 3,8 \% \\
15-34 \text { a: } 3 \% \\
35-44 \text { a: } 6,7 \%\end{array}$ \\
\hline
\end{tabular}


Cuadro 5. ESTUDIOS POBLACIONALES DE HEPATITIS B Estudios por Regiones / Departamentos.

\begin{tabular}{|c|c|c|c|c|c|}
\hline $\begin{array}{c}\text { Región } \\
\text { Departamento } \\
\text { Municipio } \\
\text { Localidad }\end{array}$ & $\begin{array}{c}\text { Autor o } \\
\text { Referencia } \\
\text { Institución }\end{array}$ & $\begin{array}{l}\text { Grupo de } \\
\text { Población } \\
\text { n individuos }\end{array}$ & $\begin{array}{c}\text { Prevalencia } \\
\text { Infección } \\
\%\end{array}$ & $\begin{array}{c}\text { Prevalencia } \\
\text { Portadores } \\
\% \\
\text { AgsHB }\end{array}$ & $\begin{array}{c}\text { Virus Delta } \\
\text { (VHD) }\end{array}$ \\
\hline $\begin{array}{l}\text { Santander } \\
\text { Barranca- } \\
\text { bermeja }\end{array}$ & $\begin{array}{l}\text { L A Villar } \\
\text { Facultad de } \\
\text { Salud UIS } \\
(41)\end{array}$ & $\begin{array}{l}\text { Donantes } \\
\text { Hospital } \\
\text { Ecopetrol } \\
n=4631 \\
n=7089\end{array}$ & $\begin{array}{c}9 \% \\
\text { ( } 422 / 4631 \\
\text { para anti-core }\end{array}$ & $\begin{array}{c}1,6 \% \\
(114 / 7089)\end{array}$ & N.R \\
\hline \multicolumn{6}{|c|}{ OCCIDENTE } \\
\hline $\begin{array}{l}\text { Antioquia } \\
\text { San Vicente } \\
\text { Las Hojas }\end{array}$ & $\begin{array}{c}\text { R.C Botero } \\
\text { Hepatología } \\
(42)\end{array}$ & $\begin{array}{l}\text { Familiares de } \\
\text { pacientes con } \\
\text { Hepatitis B } \\
n=10\end{array}$ & $80 \%$ & $70 \%$ & $\begin{array}{c}0 \% \\
(\text { Anti-VHD })\end{array}$ \\
\hline $\begin{array}{l}\text { San Vicente } \\
\text { Las Hojas }\end{array}$ & ( 43 ) & $\begin{array}{c}\text { Población } \\
n=129\end{array}$ & $17,4 \%$ & $10 \%$ & $0 \%$ \\
\hline $\begin{array}{l}\text { Jardín } \\
\text { Indígenas } \\
\text { Cristiana }\end{array}$ & $\begin{array}{c}\text { Equipo de } \\
\text { salud Jardín } \\
(44)\end{array}$ & $\begin{array}{c}\text { Resguardo } \\
\text { Indígena } \\
n=61\end{array}$ & N.R & $10 \%$ & N.R \\
\hline $\begin{array}{c}\text { Occidente } \\
\text { Antioqueño } \\
19 \text { municipios }\end{array}$ & $\begin{array}{c}\text { L.M Ochoa } \\
\text { DSSA } \\
(45)\end{array}$ & $\begin{array}{l}\text { Población } \\
>\mathbf{3 0} \text { años } \\
n=1690 \\
\text { Muestra para } \\
150.873 \text { hab }\end{array}$ & $\begin{array}{c}\text { Global: } 8,5 \% \\
\text { Occidente lejano: } \\
4,5 \% \\
\text { Occidente medio: } \\
3,8 \% \\
\text { Occidente turístico: } \\
17,3 \% \\
\text { Occidente cercano: } \\
7,8 \%\end{array}$ & $\begin{array}{c}\text { Global: } 1,1 \% \\
\begin{array}{c}0,5 \% \\
0,7 \% \\
2,7 \% \\
0,3 \%\end{array}\end{array}$ & N.R \\
\hline $\begin{array}{l}\text { Occidente } \\
\text { Antioqueño } \\
19 \text { municipios }\end{array}$ & $\begin{array}{l}n+" \text { " } \\
(45)\end{array}$ & $\begin{array}{c}\text { Población } \\
<\mathbf{3 0} \text { años } \\
n=1690 \\
\text { Muestra para } \\
\text { 150,873 hab }\end{array}$ & $\begin{array}{l}\text { Mayores } \\
\text { Prevalencias: } \\
\text { Sopetrán: } \\
23,7 \% \\
\text { Liborina: } \\
\text { 43,6\% }\end{array}$ & $\begin{array}{c}\text { Mayores } \\
\text { Prevalencias: } \\
4 \% \\
8 \%\end{array}$ & N.R \\
\hline $\begin{array}{l}\text { Frontino } \\
\text { Dabeiba }\end{array}$ & $\begin{array}{c}\text { L.M Ochoa } \\
\text { DSSA } \\
(46)\end{array}$ & $\begin{array}{c}\text { Población } \\
\text { indígena } \\
\text { Emberas } \\
\text { Katios } \\
n=830\end{array}$ & $\begin{array}{c}\text { Global: } 34,3 \% \\
\text { Frontino } \\
43,2 \% \\
\text { 5-14 a: } 28 \% \\
15-30 \text { a: } 33,5 \%\end{array}$ & $\begin{array}{c}4,2 \% \\
\text { Frontino } \\
5,7 \% \\
5 \% \\
5 \%\end{array}$ & N.R \\
\hline
\end{tabular}


Cuadro 6. ESTUDIOS POBLACIONALES DE HEPATITIS B

Estudios por Regiones / Departamentos.

\begin{tabular}{|c|c|c|c|c|c|}
\hline $\begin{array}{l}\text { Región } \\
\text { Departamento } \\
\text { Municipio } \\
\text { Localidad }\end{array}$ & $\begin{array}{l}\text { Autor o } \\
\text { Referencia } \\
\text { Institución }\end{array}$ & $\begin{array}{c}\text { Grupo de } \\
\text { Población } \\
\mathrm{n} \text { individuos }\end{array}$ & $\begin{array}{l}\text { Prevalencia } \\
\text { Infección } \\
\%\end{array}$ & $\begin{array}{c}\text { Prevalencia } \\
\text { Portadores } \\
\% \\
\text { AgsHB }\end{array}$ & $\begin{array}{l}\text { Virus Delta } \\
\text { (VHD) }\end{array}$ \\
\hline $\begin{array}{l}\text { Támesis } \\
\text { Manzanares } \\
\text { Travesías }\end{array}$ & $\begin{array}{l}\text { RE Restrepo } \\
\text { DSSA } \\
(47)\end{array}$ & $\begin{array}{c}\text { Población } \\
\text { general } \\
n=302 \\
\text { Manzanares } \\
197 \\
\text { Travesías: } \\
105\end{array}$ & $\begin{array}{c}\text { Manzanares } \\
58 \% \\
\text { 1-4a: } 40 \% \\
5-14 a: 70,6 \% \\
\text { Travesías } \\
38,1 \%\end{array}$ & $\begin{array}{c}\text { Manzanares } \\
2,5 \% \\
\text { M: } 2 \% \\
\text { 1-4a: } 10 \% \\
\text { Travesias } \\
1,9 \% \\
\text { M: } 2,2 \%\end{array}$ & N.R \\
\hline $\begin{array}{c}\text { Urrao } \\
\text { Punta Ocaidó }\end{array}$ & $\begin{array}{l}\text { MV Zea } \\
\text { Programa } \\
\text { aéreo DSSA } \\
\text { (48) }\end{array}$ & $\begin{array}{l}\text { Población } \\
\text { general } \\
58 \% \text { Raza } \\
\text { negra } \\
n=254\end{array}$ & $\begin{array}{c}\text { Global: } 82,3 \% \\
<1 \mathrm{a}: 42,8 \% \\
\text { 1-4a: } 53,4 \% \\
\text { 5-14a: } 91 \% \\
\text { 15-44a: } 90,7 \%\end{array}$ & $\begin{array}{c}9,4 \% \\
- \\
9,5 \% \\
16,2 \% \\
5,1 \%\end{array}$ & $\begin{array}{c}0 \% \\
(\text { Anti-VHD ) }\end{array}$ \\
\hline $\begin{array}{l}\text { Urabá } \\
\text { Turbo }\end{array}$ & $\begin{array}{l}\text { B. Buitrago } \\
\text { (C Jaramillo ) } \\
\text { DSSA } \\
(49)\end{array}$ & $\begin{array}{l}\text { Población } \\
\text { indígena } \\
\text { Cuna }\end{array}$ & Global: $8,7 \%$ & $0,5 \%$ & N.R \\
\hline Medellín & $\begin{array}{l}\text { B. Buitrago } \\
\text { ( M Arbeláez ) } \\
\text { (49) }\end{array}$ & $\begin{array}{l}\text { Pacientes en } \\
\text { hemodiálisis }\end{array}$ & $23 \%$ & $13 \%$ & N.R \\
\hline Medellín & $\begin{array}{l}\text { F Tirado } \\
\text { ISS } \\
(50)\end{array}$ & $\begin{array}{c}\text { Familiares de } \\
\text { portadores } \\
\text { del VHB } \\
n=157\end{array}$ & $17,2 \%$ & $10 \%$ & N.R \\
\hline $\begin{array}{l}\text { Perfil para } \\
\text { Antioquia }\end{array}$ & $\begin{array}{l}\text { DSSA } \\
(51)\end{array}$ & $\begin{array}{l}\text { Incidencia en } \\
\text { población } \\
\times 100.000\end{array}$ & $\begin{array}{l}\text { 1993: } 9,2 \\
\text { 1994: } 11,2 \\
\text { 1995: } 10,7 \\
\text { 1996: } 3,10 \\
\text { Medellín: } 0,9\end{array}$ & \multicolumn{2}{|c|}{$\begin{array}{l}\text { Promedio 1996: } \mathbf{3 , 1 0} \times \mathbf{1 0 0 , 0 0 0} \\
\text { Tasas 4-10: } 19 \text { municipios } \\
\text { Tasas 10-20: } 12 \text { municipios } \\
\text { Tasas > 20: } \mathbf{1 2} \text { municipios }\end{array}$} \\
\hline
\end{tabular}

Cuadro 7. ESTUDIOS POBLACIONALES DE HEPATITIS B Estudios por Regiones / Departamentos.

\begin{tabular}{|c|c|c|c|c|c|}
\hline $\begin{array}{c}\text { Región } \\
\text { Departamento } \\
\text { Municipio } \\
\text { Localidad }\end{array}$ & $\begin{array}{l}\text { Autor o } \\
\text { Referencia } \\
\text { Institución }\end{array}$ & $\begin{array}{l}\text { Grupo de } \\
\text { Población } \\
\mathrm{n} \text { individuos }\end{array}$ & $\begin{array}{c}\text { Prevalencia } \\
\text { Infección } \\
\%\end{array}$ & $\begin{array}{l}\text { Prevalencia } \\
\text { Portadores } \\
\% \\
\text { Ags }\end{array}$ & $\begin{array}{c}\text { Virus Delta } \\
\text { (VHD) }\end{array}$ \\
\hline$\frac{\text { Valle del }}{\frac{\text { Cauca }}{\text { Cali }}}$ & $\begin{array}{l}\text { JH Rojas } \\
\text { Secretaría de } \\
\text { Salud } \\
(52)\end{array}$ & $\begin{array}{l}\text { Prevalencia e } \\
\text { incidencias } \\
\text { Donantes y } \\
\text { población }\end{array}$ & $\begin{array}{l}\text { 1974: } 0,5 \% \\
\text { ( } 5638 \text { infectados }) \\
\text { 1994: } 5,3 \% \\
\text { (93790 infectados) }\end{array}$ & $\begin{array}{c}0,05 \% \\
\text { ( } 367 \text { portadores ) } \\
0,46 \% \\
\text { ( } 8296 \text { portadores ) }\end{array}$ & N.R \\
\hline
\end{tabular}


Continuación Cuadro 7.

\begin{tabular}{|c|c|c|c|c|c|}
\hline $\begin{array}{c}\text { Región } \\
\text { Departamento } \\
\text { Municipio } \\
\text { Localidad }\end{array}$ & $\begin{array}{c}\text { Autor o } \\
\text { Referencia } \\
\text { Institución }\end{array}$ & $\begin{array}{l}\text { Grupo de } \\
\text { Población } \\
\mathrm{n} \text { individuos }\end{array}$ & $\begin{array}{c}\text { Prevalencia } \\
\text { Infección } \\
\%\end{array}$ & $\begin{array}{c}\text { Prevalencia } \\
\text { Portadores } \\
\% \\
\text { Ags HB }\end{array}$ & $\begin{array}{l}\text { Virus Delta } \\
\text { ( VHD) }\end{array}$ \\
\hline & & \multicolumn{4}{|c|}{$\begin{array}{l}\text { Incidencia x } 100,000 \text { hab ( } 1996 \text { ) } \\
\quad \text { Tasa global: } 2,9 \\
\text { 25-29 años: } 9,28 \text { 30-34 años: } 6,67 \\
\text { 40-44 años: } 4,40 \text { 55-59 años: } 8,23 \\
\text { Asociación por comunas con cirrosis y } \\
\text { hepatocarcinoma }\end{array}$} \\
\hline $\begin{array}{l}\text { Información } \\
\text { para el Valle } \\
\text { del Cauca }\end{array}$ & $\begin{array}{l}\text { Secretaría de } \\
\text { Salud } \\
(53)\end{array}$ & $\begin{array}{l}\text { Análisis de } \\
\text { casos } \\
\text { reportados } \\
1994-1996 \\
n=119\end{array}$ & \multicolumn{3}{|c|}{$\begin{array}{c}\text { Proporción de infección por edades } \\
\text { < } 4 \text { años: } 2(1,6 \%) \quad 5-14 \text { años: } 10(8,4 \%) \\
\text { 15-44 años: } 85(71,4 \%)>45 \text { años: } 22(18,4 \%) \\
\text { Hombres: } 65 \% \text { Mujeres: } 35 \% \\
\text { Cali: } 69 \text { casos; Zarzal: } 14 \text { casos; Buga: } 8 \text { casos } \\
\text { Cartago: } 7 \text { casos; Buenaventura: } 7 \text { casos }\end{array}$} \\
\hline $\begin{array}{l}\text { Chocó } \\
\text { Urabá } \\
\text { Chintadó } \\
\text { Apartadó } \\
\text { Turbo }\end{array}$ & $\begin{array}{l}\text { M Arboleda } \\
\text { Regional } \\
\text { Urabá } \\
\text { SSSA } \\
(54)\end{array}$ & $\begin{array}{l}\text { Población } \\
\text { general y } \\
\text { personal de } \\
\text { salud } \\
n=492\end{array}$ & $32 \%$ & $\begin{array}{l}11 \% \\
(6 \% \\
\text { Adicionales } \\
\text { con infección } \\
\text { activa) }\end{array}$ & $\begin{array}{l}4 \% \\
\text { (Anti-VDH) } \\
\text { Brote HF } \\
8 \text { casos } \\
\text { certificados }\end{array}$ \\
\hline Chintadó & $\begin{array}{l}(54) \\
(54)\end{array}$ & $\begin{array}{c}\text { Chintadó } \\
n=58\end{array}$ & $50 \%$ & $8,6 \%$ & $\begin{array}{c}29 \% \\
\text { ( Anti-VHD ) }\end{array}$ \\
\hline Riosucio & & $\begin{array}{c}\text { Riosucio } \\
n=57\end{array}$ & $32 \%$ & $3,5 \%$ & $\begin{array}{c}4 \% \\
\text { (Anti-VHD) }\end{array}$ \\
\hline
\end{tabular}

Cuadro 8. ESTUDIOS POBLACIONALES DE HEPATITIS B Estudios por Regiones / Departamentos.

\begin{tabular}{|c|c|c|c|c|c|}
\hline $\begin{array}{c}\text { Región } \\
\text { Departamento } \\
\text { Municipio } \\
\text { Localidad }\end{array}$ & $\begin{array}{l}\text { Autor o } \\
\text { Referencia } \\
\text { Institución }\end{array}$ & $\begin{array}{c}\text { Grupo de } \\
\text { Población } \\
\mathrm{n} \text { individuos }\end{array}$ & $\begin{array}{c}\text { Prevalencia } \\
\text { Infección } \\
\%\end{array}$ & $\begin{array}{c}\text { Prevalencia } \\
\text { Portadores } \\
\% \\
\text { AgsHB }\end{array}$ & $\begin{array}{l}\text { Virus Delta } \\
\text { (VHD) }\end{array}$ \\
\hline $\begin{array}{c}\text { Global para } \\
\text { Chocó }\end{array}$ & $\begin{array}{l}\text { JC Padilla } \\
\text { Ministerio de } \\
\text { Salud } \\
(55)\end{array}$ & $\begin{array}{c}\text { Prevalencia } \\
\text { en al Chocó } \\
n=794\end{array}$ & - & $\begin{array}{c}\text { Global } \times 1000 \\
4,2 \\
<1 \text { año: } 74 \\
\text { 25-44 años: } 70\end{array}$ & N.R \\
\hline $\begin{array}{c}\text { Babaramá } \\
\text { Area rural de } \\
\text { Quibdó }\end{array}$ & $\begin{array}{l}\text { "1" "1" } \\
(55)\end{array}$ & $\begin{array}{c}\text { Población } \\
127 \\
\text { personas } \\
n=76\end{array}$ & $\begin{array}{c}\text { Global: } 74 \% \\
\text { Mayor frecuencia } \\
10-19 \text { años }\end{array}$ & $7 \%$ & $\stackrel{+}{\text { Casos de HF }}$ \\
\hline $\begin{array}{l}\text { Guarandó } \\
\text { Area rural de } \\
\text { Quibdó }\end{array}$ & $\begin{array}{l}\text { ("u " "" } \\
(55)\end{array}$ & $\begin{array}{l}\text { Población } \\
n=78\end{array}$ & Global: $85 \%$ & N.R & $\stackrel{+}{\text { Casos de HF }}$ \\
\hline
\end{tabular}


Continuación Cuadro 8.

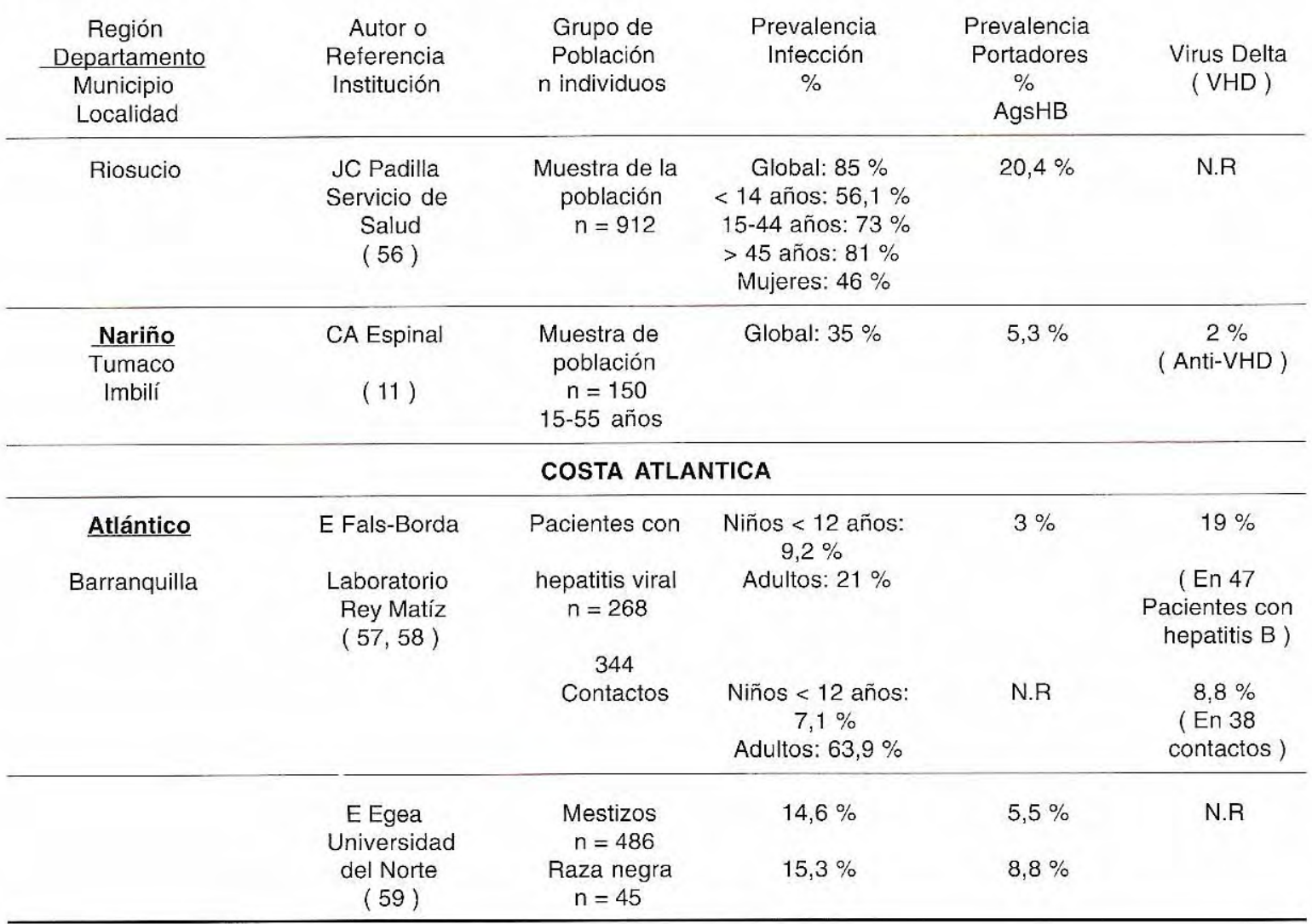

Cuadro 9. ESTUDIOS POBLACIONALES DE HEPATITIS B Estudios por Regiones / Departamentos.

\begin{tabular}{|c|c|c|c|c|c|}
\hline \multirow[t]{2}{*}{$\begin{array}{c}\text { Región } \\
\text { Departamento } \\
\text { Municipio } \\
\text { Localidad }\end{array}$} & $\begin{array}{c}\text { Autor o } \\
\text { Referencia } \\
\text { Institución }\end{array}$ & $\begin{array}{c}\text { Grupo de } \\
\text { Población } \\
n \text { individuos }\end{array}$ & $\begin{array}{c}\text { Prevalencia } \\
\text { Infección } \\
\%\end{array}$ & $\begin{array}{c}\text { Prevalencia } \\
\text { Portadores } \\
\% \\
\text { AgsHB } \\
\end{array}$ & $\begin{array}{l}\text { Virus Delta } \\
\text { ( VHD ) }\end{array}$ \\
\hline & $\begin{array}{c}\text { A Haag } \\
\text { Universidad } \\
\text { del Norte } \\
(60)\end{array}$ & $\begin{array}{c}\text { Grupos de } \\
\text { riesgo } \\
n=424\end{array}$ & $\begin{array}{c}31,7 \% \\
\text { ( Anti HBc) } \\
\text {. Trabajadoras } \\
\text { sexuales } 32,3 \% \\
\text {. Homosexuales } \\
42,6 \% \\
\text {. Hemodiálisis } \\
52,5 \% \\
\text {. Donantes } \\
15,6 \% \\
\text {. Reclusos }\end{array}$ & $\begin{array}{r}\text { Global: } 7,8 \% \\
\text { Trabajadora } \\
15 \\
\text {. Homosexua } \\
11 \\
\text {. Hemodiálisi } \\
15 \\
\text {. Donantes }\end{array}$ & $\frac{\text { N.R }}{\text { exuales }}$ \\
\hline$\frac{\text { Bolívar }}{\text { Cartagena }}$ & $\begin{array}{c}\text { D Urbina } \\
\mathrm{H} . \\
\text { Universitario } \\
(61)\end{array}$ & $\begin{array}{c}\text { Pacientes } \\
\text { Unidad de } \\
\text { infecciosas } \\
\text { Hemodiálisis } \\
n=21\end{array}$ & $52,3 \%$ & $9,5 \%$ & N.R \\
\hline
\end{tabular}


Continuación Cuadro 9.

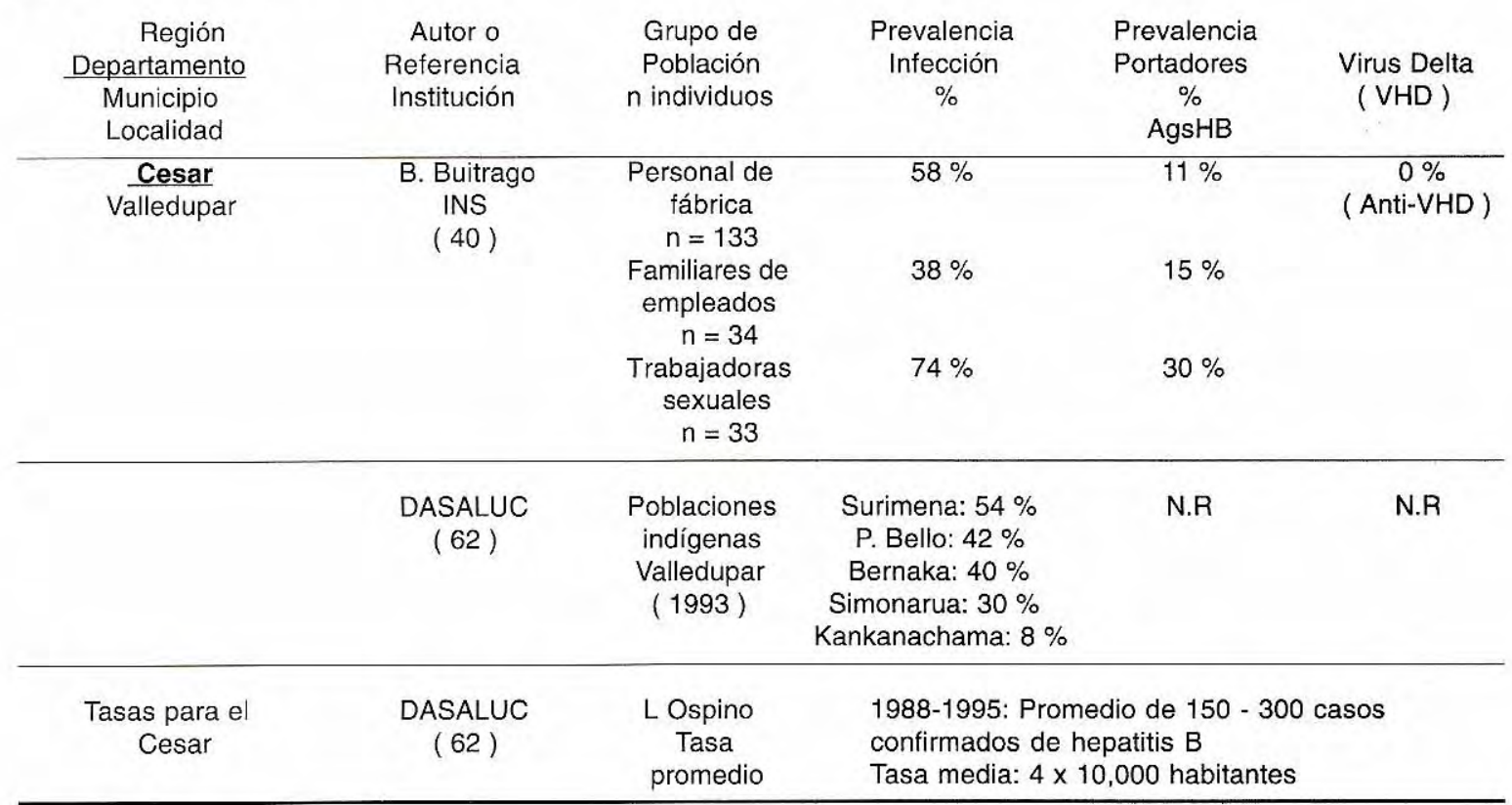

Cuadro 10. ESTUDIOS POBLACIONALES DE HEPATITIS B Estudios por Regiones / Departamentos.

\begin{tabular}{|c|c|c|c|c|c|}
\hline $\begin{array}{c}\begin{array}{c}\text { Región } \\
\text { Departamento }\end{array} \\
\text { Municipio } \\
\text { Localidad }\end{array}$ & $\begin{array}{c}\text { Autor o } \\
\text { Referencia } \\
\text { Institución }\end{array}$ & $\begin{array}{c}\text { Grupo de } \\
\text { Población } \\
\mathrm{n} \text { individuos }\end{array}$ & $\begin{array}{c}\text { Prevalencia } \\
\text { Infección } \\
\%\end{array}$ & $\begin{array}{c}\text { Prevalencia } \\
\text { Portadores } \\
\% \\
\text { AgsHB }\end{array}$ & $\begin{array}{c}\text { Virus Delta } \\
\text { ( VHD ) }\end{array}$ \\
\hline Cesar & $\begin{array}{l}\text { DASALUC } \\
(63)\end{array}$ & $\begin{array}{l}\text { Bancos de } \\
\text { sangre } 1995 \\
\text { ( Enero- } \\
\text { septiembre) }\end{array}$ & $\begin{array}{c}\text { Global } 14,8 \% \\
\text { ( Anti-HBc) } \\
14,9 \% \\
14,4 \% \\
\text { Ba } \\
\text { N.R }\end{array}$ & $\begin{array}{r}\text { Global: } 2,6 \% \\
\text { anco Cruz Roja } \\
\text { 2,9\% } \\
\text { anco Hospital Ros. } \\
\text { 1,6\% } \\
\text { anco Hospital Ague } \\
2,0 \%\end{array}$ & $\begin{array}{l}\text { N.R } \\
\text { Pum de López } \\
\text { Chica }\end{array}$ \\
\hline $\begin{array}{l}\text { Resguardo } \\
\text { indígena de } \\
\text { los Arhuacos }\end{array}$ & $\begin{array}{c}\text { G Espinosa } \\
\text { INS } \\
(64)\end{array}$ & $\begin{array}{c}\text { Indígenas } \\
\text { Arhuacos } \\
n=864 \\
\text { Mayores de } 5 \\
\text { años de edad }\end{array}$ & $\begin{array}{c}21,1 \% \\
\text { Hombres }<15 \text { años: } \\
31,5 \% \\
\text { Menores de } 12 \text { años: } \\
12 \% \\
\text { Mujeres } 15-25 \text { años: } \\
24 \% \\
\text { Mujeres } 26-42 \text { años: } \\
34 \%\end{array}$ & $\begin{array}{c}2,8 \% \\
\text { Mujeres en edad } \\
\text { fértil: } 0,08 \%\end{array}$ & $\begin{array}{c}\stackrel{+}{\text { Brotes fatales }} \\
\text { de hepatitis } \\
\text { fulminante }\end{array}$ \\
\hline 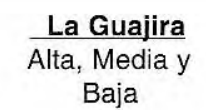 & $\begin{array}{l}\text { A. Aguilera } \\
\text { INS } \\
(65)\end{array}$ & $\begin{array}{c}\text { Población } \\
n=1045\end{array}$ & $35 \%$ & $4,4 \%$ & N.R \\
\hline
\end{tabular}


Continuación Cuadro 10.

\begin{tabular}{|c|c|c|c|c|c|}
\hline $\begin{array}{c}\text { Región } \\
\text { Departamento } \\
\text { Municipio } \\
\text { Localidad }\end{array}$ & $\begin{array}{l}\text { Autor o } \\
\text { Referencia } \\
\text { Institución }\end{array}$ & $\begin{array}{c}\text { Grupo de } \\
\text { Población } \\
n \text { individuos }\end{array}$ & $\begin{array}{c}\text { Prevalencia } \\
\text { Infección } \\
\%\end{array}$ & $\begin{array}{c}\text { Prevalencia } \\
\text { Portadores } \\
\% \\
\text { Ags HB }\end{array}$ & $\begin{array}{l}\text { Virus Delta } \\
\text { ( VHD ) }\end{array}$ \\
\hline $\begin{array}{l}\text { Comunidad } \\
\text { Indígena }\end{array}$ & $\begin{array}{l}\text { E. Egea } \\
\text { Universidad } \\
\text { del Norte } \\
(66)\end{array}$ & $\begin{array}{l}\text { Población } \\
\text { Wayuu } \\
n=170\end{array}$ & $11,7 \%$ & $0 \%$ & N.R \\
\hline Magdalena & B. Buitrago & Riofrío & $56 \%$ & $9 \%$ & $6 \%$ \\
\hline Area rural de & ( M. Martínez ) & Santa Rosalía & $69 \%$ & $11 \%$ & $25 \%$ \\
\hline Ciénaga & INS & Varela & $51 \%$ & $11 \%$ & $7 \%$ \\
\hline 1984-1985 & $(67,68)$ & Julio Zawady & $\begin{array}{c}75 \% \\
\text { Global: } 68 \%\end{array}$ & $\begin{array}{c}18 \% \\
\text { Global: } 12 \%\end{array}$ & $\begin{array}{c}63 \% \\
\text { Global: } 25 \% \\
5-9 \text { a: } 25 \% \\
10-15 \text { a: } 29 \%\end{array}$ \\
\hline
\end{tabular}

Cuadro 11. ESTUDIOS POBLACIONALES DE HEPATITIS B

Estudios por Regiones / Departamentos.

\begin{tabular}{|c|c|c|c|c|c|}
\hline $\begin{array}{c}\begin{array}{c}\text { Región } \\
\text { Departamento }\end{array} \\
\text { Municipio } \\
\text { Localidad }\end{array}$ & $\begin{array}{l}\text { Autor o } \\
\text { Referencia } \\
\text { Institución }\end{array}$ & $\begin{array}{c}\text { Grupo de } \\
\text { Población } \\
n \text { individuos }\end{array}$ & $\begin{array}{c}\text { Prevalencia } \\
\text { Infección } \\
\%\end{array}$ & $\begin{array}{c}\text { Prevalencia } \\
\text { Portadores } \\
\% \\
\text { AgsHB }\end{array}$ & $\begin{array}{c}\text { Virus Delta } \\
(\text { VHD ) }\end{array}$ \\
\hline \multirow{2}{*}{$\begin{array}{l}\text { Area rural } \\
\text { Ciénaga }\end{array}$} & \multirow{6}{*}{$\begin{array}{c}\text { F de la Hoz } \\
\text { INS } \\
(69,70,71)\end{array}$} & \multirow{2}{*}{$\begin{array}{c}\text { Globales: } \\
n=2435 \\
\text { Varela } \\
n=773\end{array}$} & $58 \%$ & $7,5 \%$ & \multirow{2}{*}{$\begin{array}{l}\text { N.R } \\
\text { N.R }\end{array}$} \\
\hline & & & $\begin{array}{c}25 \% \\
\text { < } 5 \text { años: } 3 \% \\
\text { 10-14 años: } 13 \% \\
\text { 15-24 años: } 49 \% \\
>45 \text { años: } 70 \%\end{array}$ & $\begin{array}{c}2 \% \\
\text { Mujeres: } 1,4 \% \\
15-44 \text { años: } 4 \%\end{array}$ & \\
\hline \multirow[t]{4}{*}{$\because=$} & & $\begin{array}{c}\text { Cerro Azul } \\
n=405\end{array}$ & $\begin{array}{c}75 \% \\
<5 \text { años: } 54 \%\end{array}$ & $\begin{array}{c}13 \% \\
\text { Mujeres: } 10 \% \\
<1 \text { año: } 27 \% \\
2-9 \text { años: } 17 \%\end{array}$ & N.R \\
\hline & & $\begin{array}{l}\text { Julio Zawady } \\
\qquad n=571\end{array}$ & $\begin{array}{c}71 \% \\
<1 \text { año: } 22 \% \\
<45 \text { años: } 91 \%\end{array}$ & $\begin{array}{c}10 \% \\
\text { Mujeres: } 11 \% \\
<1 \text { año: } 9 \%\end{array}$ & N.R \\
\hline & & $\begin{array}{c}\text { Santa Rosalía } \\
n=686\end{array}$ & $\begin{array}{c}65 \% \\
<1 \text { año: } 23 \%\end{array}$ & $\begin{array}{c}9 \% \\
\text { Mujeres: } 8 \% \\
<1 \text { año: } 2 \%\end{array}$ & \multirow{2}{*}{ N.R } \\
\hline & & $\begin{array}{l}\text { Incidencia } \\
\text { acumulada } \\
n=167\end{array}$ & $\begin{array}{c}25 \% \\
\text { (Observación de } \\
70 \text { días ) }\end{array}$ & 2-9 años: $11 \%$ & \\
\hline $\begin{array}{l}\text { Area rural de } \\
\text { Ciénaga }\end{array}$ & $\begin{array}{c}\text { K. } \\
\text { Ljunggren } \\
\text { H. de Lund } \\
\text { Suecia } \\
(31)\end{array}$ & $\begin{array}{c}\text { Población } \\
\text { Julio Zawady } \\
\text { Santa Rosalía } \\
\text { Aracataca } \\
n=1,444\end{array}$ & Global: $70,1 \%$ & Global: $12,4 \%$ & $\begin{array}{l}\text { Anti-VHD: } \\
6 \text { positivos } \\
\text { AgVHD: } \\
1 \text { positivo } \\
\text { ( Entre } 10 \\
\text { Ags } \mathrm{HB}+\text { ) }\end{array}$ \\
\hline $\begin{array}{c}\text { Area rural de } \\
\text { Ciénaga }\end{array}$ & $\begin{array}{c}\text { A Villanueva } \\
\text { Hospital San } \\
\text { Juan de Dios } \\
\text { Santa Marta } \\
(72)\end{array}$ & $\begin{array}{c}\text { Santa Rosalía } \\
\text { Julio Zawady } \\
\text { Aracataca } \\
\text { Santa Marta } \\
n=258\end{array}$ & $\begin{array}{r}30 \% \\
55 \% \\
2,5 \% \\
48,5 \%\end{array}$ & & $\begin{array}{c}22 \% \\
13,7 \% \\
0 \% \\
0 \% \\
20 \text { pacientes } \\
\text { fallecidos con } \\
\text { HF }\end{array}$ \\
\hline
\end{tabular}


Cuadro 12. PREVALENCIA EN BANCOS DE SANGRE INSTITUTO NACIONAL DE SALUD COORDINACION NACIONAL DE BANCOS DE SANGRE

\begin{tabular}{|c|c|c|c|}
\hline Departamento & $\begin{array}{c}1994(73) \\
\text { AgsHB \% }\end{array}$ & $\begin{array}{l}1995(74) \\
\text { AgsHB \% }\end{array}$ & $\begin{array}{c}1997 \text { ( Enero-Agosto ) } \\
\text { Anti-HBc \% ( } 75 \text { ) }\end{array}$ \\
\hline Amazonas & 2,9 & 2,5 & - \\
\hline Caquetá & 3,3 & Guaviare: $3,3 \%$ & - \\
\hline Putumayo & 1,5 & 0,6 & - \\
\hline Arauca & 1,3 & 1,9 & 12,8 \\
\hline Casanare & 5,2 & 2,5 & - \\
\hline Guainía & 4,9 & - & - \\
\hline Meta & 2,1 & 1,5 & - \\
\hline Vaupés & 4,6 & - & - \\
\hline Vichada & - & 8,4 & 3,8 \\
\hline Norte de Santander & 2,0 & 3,9 & - \\
\hline Santander & 1,6 & 1,2 & - \\
\hline Antioquia & 2,3 & 1,0 & - \\
\hline Valle del Cauca & 1,2 & San Andres: 1,9 \% & Valle del Cauca; 6,9 \\
\hline Cesar & 2,4 & 2,6 & 10,1 \\
\hline Guajira & 1,9 & 2,1 & - \\
\hline Magdalena & 1,2 & 4,3 & 13,8 \\
\hline Promedio nacional & 1,0 & 0,9 & 4,4 \\
\hline $\begin{array}{l}\text { B. Buitrago } \\
\text { ( C Jaramillo ) ( } 49 \text { ) } \\
\text { * Donantes sanos } \\
\text { Medellín ( } 1975 \text { ) } \\
\text { * Donantes en } 4 \\
\text { ciudades ( } 1976 \text { ) } \\
\text { Medellín Bogotá Cali } \\
\text { Bucaramanga }\end{array}$ & $\begin{array}{c}\text { AgsHB } \\
2,8 \% \\
\text { Global: } 1,0 \%\end{array}$ & Ant & \\
\hline $\begin{array}{c}\text { E Duque } \\
\mathrm{H} \cup \text { del Valle }(76)\end{array}$ & $0,55 \%$ & \multicolumn{2}{|c|}{-} \\
\hline $\begin{array}{c}\text { A Haag } \\
\text { H. Universitario de } \\
\text { Barranquilla } \\
(60)\end{array}$ & $\begin{array}{l}\frac{\text { Año }}{1993} \\
1994 \\
1995 \\
\end{array}$ & $\begin{array}{c}\text { No donantes } \\
3190 \\
2303 \\
2367\end{array}$ & $\begin{array}{c}\text { Ags HB \% } \\
0,9 \\
1,6 \\
1,7\end{array}$ \\
\hline $\begin{array}{c}\text { D Urbina } \\
\text { H. Universitario } \\
\text { Cartagena }(77 \text { ) }\end{array}$ & 1989 & 240 & 2,0 \\
\hline
\end{tabular}


Cuadro 13. ESTUDIOS POBLACIONALES DE HEPATITIS B

Estudios por Regiones / Departamentos

ESTUDIOS EN COMUNIDADES INDIGENAS.

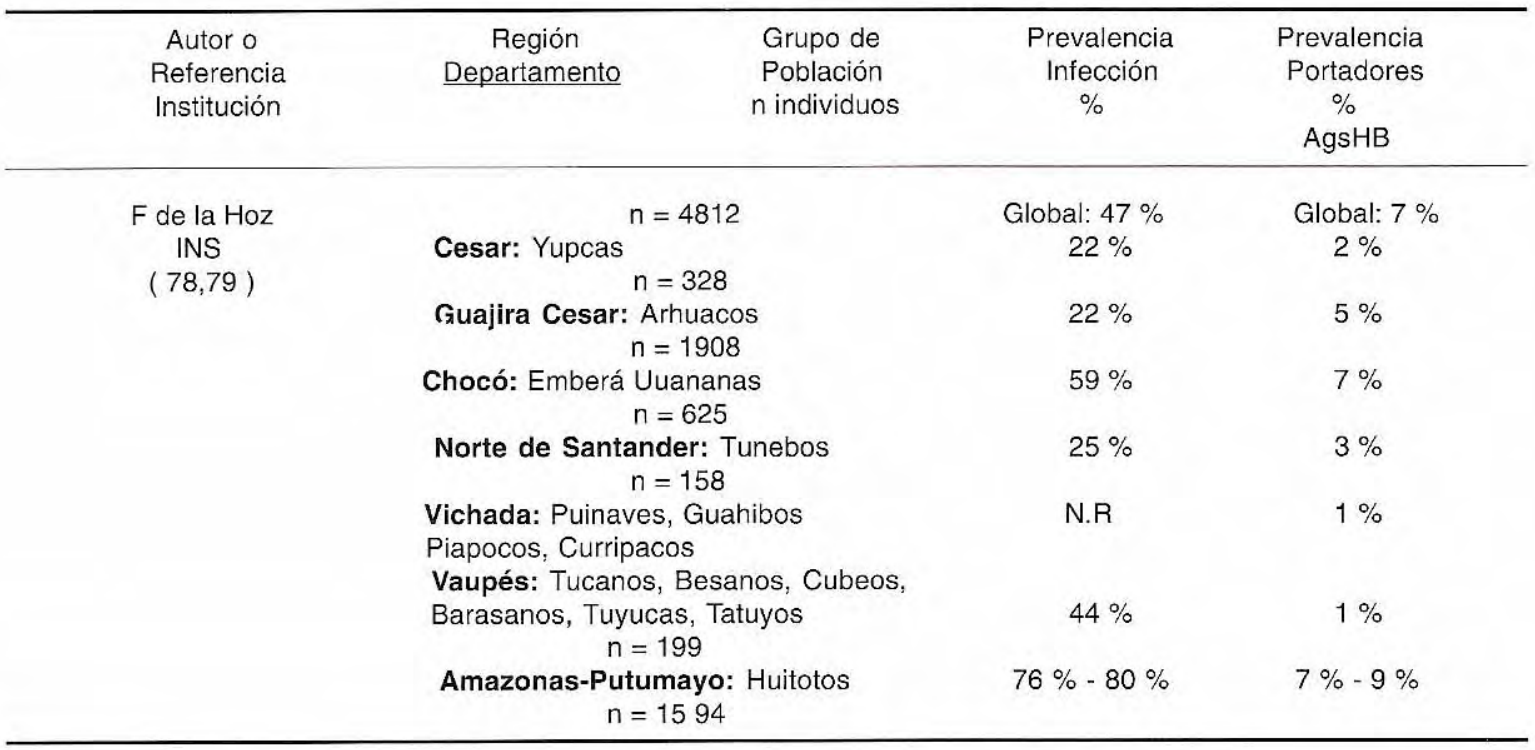

Cuadro 14. ESTUDIOS POBLACIONES DE HEPATITIS B

Estudios por Regiones / Departamentos ESTUDIOS EN COMUNIDADES INDIGENAS.

\begin{tabular}{|c|c|c|c|c|}
\hline $\begin{array}{l}\text { Autor o } \\
\text { Referencia } \\
\text { Institución }\end{array}$ & $\begin{array}{c}\text { Región } \\
\text { Departamento }\end{array}$ & $\begin{array}{l}\text { Grupo de } \\
\text { Población } \\
n \text { individuos }\end{array}$ & $\begin{array}{c}\text { Prevalencia } \\
\text { Infección } \\
\%\end{array}$ & $\begin{array}{c}\text { Prevalencia } \\
\text { Portadores } \\
\% \\
\text { AgsHB }\end{array}$ \\
\hline $\begin{array}{l}\text { J Bernal } \\
\text { Expedición }\end{array}$ & \multicolumn{2}{|c|}{$\begin{aligned} \text { Cauca ( Timbiquí ): Emberá-Epena } \\
$\[ \mathrm{n}=50 \]$\end{aligned}$} & $92 \%$ & $34 \%$ \\
\hline $\begin{array}{l}\text { Humara } \\
\text { Universidad }\end{array}$ & \multicolumn{2}{|c|}{$\begin{array}{l}\text { Chocó: Waunana de Papayo ( Río San } \\
\text { Juan) } n=45\end{array}$} & $31 \%$ & $18 \%$ \\
\hline $\begin{array}{c}\text { Javeriana } \\
(80,81)\end{array}$ & \multicolumn{2}{|c|}{$\begin{array}{l}\text { Darién ( Chocó-Antioquia ): Cuna } \\
\qquad n=49 \\
\text { Sierra Nevada de Santa Marta: }\end{array}$} & $24 \%$ & $8 \%$ \\
\hline & \multicolumn{2}{|c|}{ Kogi $\quad n=50$} & $83 \%$ & $31 \%$ \\
\hline & & $60 \%$ & N.R \\
\hline & Wiwas & & $90 \%$ & N.R \\
\hline & \multicolumn{2}{|c|}{$\begin{array}{l}\qquad n=62 \\
\text { Guajira: Wayuu de Sucarama }\end{array}$} & $5 \%$ & $0 \%$ \\
\hline & \multicolumn{2}{|c|}{$\begin{array}{c}n=39 \\
\text { Cesar: Arhuacos de Simonaura y }\end{array}$} & $19 \%$ & $3 \%$ \\
\hline & \multicolumn{2}{|c|}{$\begin{array}{ll}\text { Nabusimake } & n=184 \\
\text { Cesar (Serranía del Perijá ): }\end{array}$} & $39 \%$ & $6 \%$ \\
\hline & \multicolumn{2}{|c|}{$\begin{array}{l}\text { Yuco-Yukpa } n=63 \\
\text { Santander: Guane }\end{array}$} & $82 \%$ & $33 \%$ \\
\hline & \multicolumn{2}{|c|}{$\begin{array}{l}\text { Santander: Guane } \\
\qquad n=25 \\
\text { Norte de Santander: Motilones }\end{array}$} & $72 \%$ & $36 \%$ \\
\hline
\end{tabular}


Continuación Cuadro 14.

Autor o

Referencia Institución
Grupo de
Población
n individuos

$n=71$

Meta ( Puerto Gaitán ): Sikuani de Walabó $n=55$

Guahibos Caño Jabón: $n=31$

Guahibos Yopalito: $\quad n=32$

Gauyabero del Barranco: $n=20$

Caquetá Río Orteguaza: Coreguajes

$$
n=50
$$

Vaupés: Tukano

$$
n=46
$$

\section{Prevalencia Infección \\ $\%$}

Prevalencia
Portadores
$\%$

AgsHB

$\begin{array}{lc}65 \% & 15 \% \\ 64 \% & 33 \% \\ 90 \% & 0 \% \\ 38 \% & 10 \% \\ 85 \% & 0 \% \\ 18 \% & 4 \% \\ 92 \% & 7 \%\end{array}$

\section{Comunidades de raza negra:}

Chocó: Vigía del Fuerte: $n=24$

Bahía Zolano: $\mathrm{n}=16$

Providencia ( San Andrés ): $n=44$

$\begin{array}{cc}84 \% & 17 \% \\ 31 \% & 19 \% \\ 30 \% & 5 \%\end{array}$

Cuadro 15. ESTUDIOS SOBRE HEPATITIS B EN EL SECTOR SALUD

\begin{tabular}{|c|c|c|c|c|}
\hline $\begin{array}{c}\text { Región } \\
\text { Departamento } \\
\text { Municipio } \\
\text { Localidad }\end{array}$ & $\begin{array}{c}\text { Autor o } \\
\text { Referencia } \\
\text { Institución }\end{array}$ & $\begin{array}{c}\text { Población } \\
n \\
\text { individuos }\end{array}$ & $\begin{array}{l}\text { Prevalencia } \\
\text { Infección } \\
\%\end{array}$ & $\begin{array}{c}\text { Prevalencia } \\
\text { Portadores } \\
\text { AgsHB } \\
\%\end{array}$ \\
\hline \multicolumn{5}{|c|}{ AMAZONIA-ORINOQUIA } \\
\hline Vaupés & $\begin{array}{c}\text { Servicio } \\
\text { Seccional de } \\
\text { Salud } \\
(40)\end{array}$ & $\begin{array}{c}\text { Funcionarios del } \\
\text { Servicio } \\
n=72 \\
\text { Indígenas } \\
\text { Cubeos }\end{array}$ & $35 \%$ & N.R \\
\hline \multicolumn{5}{|c|}{ CENTRO ORIENTE } \\
\hline \multirow[t]{4}{*}{$\frac{\text { Santa Fe de }}{\underline{\text { Bogotá }}}$} & $\begin{array}{c}\text { J Saravia } \\
\text { Hospital San } \\
\text { Juan de Dios } \\
\text { (82) }\end{array}$ & $\begin{array}{c}\text { Personal del } \\
\text { Hospital } \\
n=188\end{array}$ & $44,3 \%$ & $17,6 \%$ \\
\hline & $\begin{array}{c}\text { R C Botero } \\
\text { Fundación } \\
\text { Santa Fe } \\
(83)\end{array}$ & $\begin{array}{c}\text { Personal de } \\
\text { salud } \\
n=266\end{array}$ & $13 \%$ & $0,75 \%$ \\
\hline & $\begin{array}{l}\text { Clínica Palermo } \\
(40)\end{array}$ & $\begin{array}{c}\text { Personal de } \\
\text { salud } \\
n=192\end{array}$ & $2,6 \%$ & $2,6 \%$ \\
\hline & $\begin{array}{l}\text { C Espinal } \\
\text { Hospital de la } \\
\text { Samaritana }\end{array}$ & $\begin{array}{c}\text { Personal del } \\
\text { Hospital } \\
n=835\end{array}$ & $14,6 \%$ & $0,5 \%$ \\
\hline
\end{tabular}
Estudios por Regiones / Departamentos. 
Continuación Cuadro 15.

\begin{tabular}{|c|c|c|c|c|}
\hline $\begin{array}{c}\begin{array}{c}\text { Región } \\
\text { Departamento }\end{array} \\
\text { Municipio } \\
\text { Localidad }\end{array}$ & $\begin{array}{c}\text { Autor o } \\
\text { Referencia } \\
\text { Institución }\end{array}$ & $\begin{array}{l}\text { Población } \\
n \\
\text { individuos }\end{array}$ & $\begin{array}{l}\text { Prevalencia } \\
\text { Infección } \\
\%\end{array}$ & $\begin{array}{c}\text { Prevalencia } \\
\text { Portadores } \\
\text { AgsHB } \\
\%\end{array}$ \\
\hline & $\begin{array}{l}\text { O Juliao } \\
\text { INS } \\
(84)\end{array}$ & $\begin{array}{c}\text { Funcionarios del } \\
\text { INS } \\
n=334\end{array}$ & $13 \%$ & $1,8 \%$ \\
\hline & $\begin{array}{l}\text { S Henao } \\
\text { Cajanal } \\
(16)\end{array}$ & $\begin{array}{l}\text { Funcionarios } \\
n=174\end{array}$ & $11 \%$ & $0,6 \%$ \\
\hline & $\begin{array}{l}\text { G Plata } \\
\text { Hospital Militar } \\
\text { Central } \\
\text { (85) }\end{array}$ & $\begin{array}{c}\text { Personal del } \\
\text { Hospital } \\
n=898\end{array}$ & $9,9 \%$ & $0,5 \%$ \\
\hline
\end{tabular}

Cuadro 16. ESTUDIOS SOBRE HEPATITIS B EN EL SECTOR SALUD Estudios por Regiones / Departamentos

\begin{tabular}{|c|c|c|c|c|}
\hline $\begin{array}{c}\text { Región } \\
\text { Departamento } \\
\text { Municipio } \\
\text { Localidad }\end{array}$ & $\begin{array}{c}\text { Autor o } \\
\text { Referencia } \\
\text { Institución }\end{array}$ & $\begin{array}{c}\text { Población } \\
n \\
\text { individuos }\end{array}$ & $\begin{array}{c}\text { Prevalencia } \\
\text { Infección } \\
\%\end{array}$ & $\begin{array}{c}\text { Prevalencia } \\
\text { Portadores } \\
\text { AgsHB }\end{array}$ \\
\hline & $\begin{array}{l}\text { R C Botero } \\
\text { Fundación } \\
\text { Santa Fe } \\
\text { ( } 86)\end{array}$ & $\begin{array}{c}\text { Médicos } \\
n=408 \\
\text { Paramédicos } \\
n=89 \\
\text { Congreso } \\
\text { Colombiano de } \\
\text { Medicina Interna } \\
1992\end{array}$ & $\begin{array}{c}7,6 \% \\
\text { Amazonía y } \\
\text { Llanos } \\
\text { Orientales: } \\
\text { 16,7 \% } \\
\text { Santanderes: } \\
13,6 \%\end{array}$ & $0,4 \%$ \\
\hline & $\begin{array}{c}\text { Secretaría de } \\
\text { Salud } \\
\text { Vigilancia } \\
\text { Epidemiológica } \\
\text { ( } 87 \text { ) }\end{array}$ & $\begin{array}{c}\text { Funcionarios del } \\
\text { Servicio } \\
n=3640\end{array}$ & $\begin{array}{c}8,3 \% \\
\text { Odontólogos: } \\
11,5 \% \\
\text { Enfermeras jefes: } \\
14,6 \% \\
\text { Cirujanos: } \\
9 \%\end{array}$ & $\begin{array}{l}0,43 \% \\
2,7 \% \\
2,9 \%\end{array}$ \\
\hline & $\begin{array}{l}\text { S Pimiento } \\
\text { Fundación } \\
\text { Santa Fe } \\
\text { ( } 88)\end{array}$ & $\begin{array}{c}\text { Exposición por } \\
\text { accidentes de } \\
\text { trabajo } \\
n=114\end{array}$ & $\begin{array}{c}20 \% \\
\text { ( Seroconversión ) }\end{array}$ & N.R \\
\hline & $\begin{array}{l}\text { H. Fajardo } \\
\text { Hospital San } \\
\text { Juan de Dios } \\
\text { Instituto } \\
\text { Materno Infantil } \\
\text { (89) }\end{array}$ & $\begin{array}{c}\text { Trabajadores de } \\
\text { salud } \\
n=2,306 \\
\text { HSJD: } 1617 \\
\text { IMI: } 689\end{array}$ & $\begin{array}{c}\text { Global: } 13,1 \% \\
\text { HSJD } \\
\text { Cirugía: } 20 \% \\
\text { U. Renal: } 33 \% \\
\text { Neurocirugia: } \\
33 \% \\
\text { Oftalmología: } \\
21,4 \%\end{array}$ & $\frac{\text { HSJD }}{0,6 \%}$ \\
\hline
\end{tabular}


Cuadro 17. ESTUDIOS SOBRE HEPATITIS B EN EL SECTOR SALUD Estudios por Regiones / Departamentos.

\begin{tabular}{|c|c|c|c|}
\hline $\begin{array}{c}\begin{array}{c}\text { Región } \\
\text { Departamento }\end{array} \\
\text { Municipio } \\
\text { Localidad }\end{array}$ & $\begin{array}{l}\text { Autor o } \\
\text { Referencia } \\
\text { Institución }\end{array}$ & $\begin{array}{c}\text { Prevalencia } \\
\text { Infección } \\
\%\end{array}$ & $\begin{array}{c}\text { Prevalencia } \\
\text { Portadores } \\
\text { AgsHB } \\
\%\end{array}$ \\
\hline \multicolumn{4}{|c|}{ ESTUDIOS MULTICENTRICOS } \\
\hline \multicolumn{4}{|c|}{$\begin{array}{l}\text { C Jaramillo ( } 90 \text { ) } \\
\text { Instituto de Seguro Social }\end{array}$} \\
\hline \multicolumn{4}{|c|}{ Población: 10,946 funcionarios de 22 secionales } \\
\hline & Resultados Globales & $21,6 \%$ & $1,7 \%$ \\
\hline & Región Andina & $24,4 \%$ & $1,2 \%$ \\
\hline & Región Atlántica & $23,9 \%$ & $3,5 \%$ \\
\hline & Región Pacífica & $9,5 \%$ & $1,3 \%$ \\
\hline & Región Orinoquía & $19,6 \%$ & $5,4 \%$ \\
\hline & Región Amazonia & - & $7,7 \%$ \\
\hline & Ocupación: Médicos & $21,4 \%$ & N.R \\
\hline & Odontólogos & $8,2 \%$ & N.R \\
\hline & Auxiliares & $44 \%$ & N.R \\
\hline & Enfermeras & $9,8 \%$ & N.R \\
\hline \multicolumn{4}{|c|}{$\begin{array}{l}\text { Instituto Nacional de Salud ( } 91 \text { ) } \\
\text { IPS propias y afiliadas }\end{array}$} \\
\hline \multicolumn{4}{|c|}{ Población: 2,149 funcionarios en 10 ciudades } \\
\hline & os Globales & $5,7 \%$ & $0,7 \%$ \\
\hline & Auxiliares de enfermería & $6,6 \%$ & N.R \\
\hline & Laboratorio & $7,2 \%$ & N.R \\
\hline & Odontología & $6,6 \%$ & \\
\hline
\end{tabular}

Cuadro 18. ESTUDIOS SOBRE HEPATITIS B EN EL SECTOR SALUD Estudios por Regiones / Departamentos

\begin{tabular}{|c|c|c|c|c|}
\hline $\begin{array}{c}\text { Región } \\
\text { Departamento } \\
\text { Municipio } \\
\text { Localidad }\end{array}$ & $\begin{array}{c}\text { Autor o } \\
\text { Referencia } \\
\text { Institución }\end{array}$ & $\begin{array}{c}\text { Población } \\
n \\
\text { individuos }\end{array}$ & $\begin{array}{c}\text { Prevalencia } \\
\text { Infección } \\
\%\end{array}$ & $\begin{array}{c}\text { Prevalencia } \\
\text { Portadores } \\
\text { AgsHB } \\
\%\end{array}$ \\
\hline \multicolumn{5}{|c|}{ OCCIDENTE } \\
\hline \multirow[t]{2}{*}{$\frac{\text { Antioquia }}{\text { Medellín }}$} & $\begin{array}{l}\text { ML Arroyave } \\
\text { Laboratorio } \\
\text { Departamental } \\
\text { SSSA } \\
(92)\end{array}$ & $\begin{array}{l}\text { Personal de } \\
\text { salud de } \\
\text { instituciones } \\
n=762\end{array}$ & \multicolumn{2}{|c|}{$\begin{array}{l}\text { Portadores } \\
\text { Médicos: } 8 \% \text { Enfermeras: } 23,8 \% \\
\text { Bacteriólogas: } 15,7 \% \\
\text { Auxiliares odontología: } 19 \% \\
\text { Auxiliares laboratorio: } 16,6 \%\end{array}$} \\
\hline & $\begin{array}{l}\text { F Tirado } \\
\text { ISS ( } 50)\end{array}$ & $\begin{array}{c}\text { Funcionarios ISS } \\
n=2067\end{array}$ & $11,1 \%$ & $2,3 \%$ \\
\hline
\end{tabular}


Continuación Cuadro 18.

\begin{tabular}{|c|c|c|c|c|}
\hline $\begin{array}{l}\text { Región } \\
\text { Departamento } \\
\text { Municipio } \\
\text { Localidad }\end{array}$ & $\begin{array}{l}\text { Autor o } \\
\text { Referencia } \\
\text { Institución }\end{array}$ & $\begin{array}{c}\text { Población } \\
n \\
\text { individuos }\end{array}$ & $\begin{array}{c}\text { Prevalencia } \\
\text { Infección } \\
\%\end{array}$ & $\begin{array}{c}\text { Prevalencia } \\
\text { Portadores } \\
\text { AgsHB } \\
\%\end{array}$ \\
\hline & $\begin{array}{c}\text { ML Arroyave } \\
\text { HU San Vicente } \\
\text { de Paul } \\
(93)\end{array}$ & $\begin{array}{c}\text { Funcionarios del } \\
\text { Hospital } \\
n=981\end{array}$ & $\begin{array}{c}11,9 \% \\
\text { Laboratorio: } \\
29,2 \% \\
\text { Médicos: } 16 \%\end{array}$ & $\begin{array}{c}0,6 \% \\
3,2 \% \\
\text { En ventana }\end{array}$ \\
\hline $\begin{array}{l}\text { Urabá } \\
\text { Apartadó } \\
\text { Turbo } \\
\text { Riosucio }\end{array}$ & $\begin{array}{c}\text { M Arboleda } \\
\text { Regional Urabá } \\
\text { SSSA } \\
(54)\end{array}$ & $\begin{array}{l}\text { Personal de } \\
\text { salud } \\
n=376\end{array}$ & $\begin{array}{ll}31,1 \% & \\
& \\
25 \% & \text { E } \\
29 \% \quad \text { Viru } & \end{array}$ & 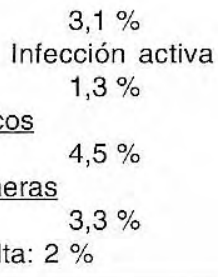 \\
\hline Antioquia & $\begin{array}{c}\text { A Arroyave } \\
\text { DSSA } \\
(94)\end{array}$ & $\begin{array}{c}\text { Funcionarios del } \\
\text { Servicio } \\
n=7,722 \\
\text { Municipios de } \\
\text { > prevalencia } \\
\text { Santa Barbara } \\
\text { Heliconia } \\
\text { Guarne } \\
\text { Valdivia }\end{array}$ & $\begin{array}{r}14,3 \% \\
46,7 \% \\
17,6 \% \\
48 \%\end{array}$ & $\begin{array}{r}14,3 \% \\
13,3 \% \\
11,8 \% \\
8 \%\end{array}$ \\
\hline
\end{tabular}

Cuadro 19. ESTUDIOS SOBRE HEPATITIS B EN EL SECTOR SALUD Estudios por Regiones / Departamentos

\begin{tabular}{|c|c|c|c|c|}
\hline $\begin{array}{l}\begin{array}{l}\text { Región } \\
\text { Departamento }\end{array} \\
\text { Municipio } \\
\text { Localidad }\end{array}$ & $\begin{array}{c}\text { Autor o } \\
\text { Referencia } \\
\text { Institución }\end{array}$ & $\begin{array}{l}\text { Población } \\
n \\
\text { individuos }\end{array}$ & $\begin{array}{c}\text { Prevalencia } \\
\text { Infección } \\
\%\end{array}$ & $\begin{array}{l}\text { Prevalencia } \\
\text { Portadores } \\
\text { AgsHB } \\
\%\end{array}$ \\
\hline \multicolumn{5}{|c|}{$\begin{array}{l}\text { Estudio Multicéntrico } \\
\text { ARP Seguro Social } \\
\text { M Serra ( } 95 \text { ) } \\
\text { de Investigaciones Epidemiológicas } \\
\text { Universidad del Valle }\end{array}$} \\
\hline \multicolumn{3}{|c|}{$\mathrm{n}=698$ trabajadores } & Global: $15,7 \%$ & Global: $2,2 \%$ \\
\hline \multicolumn{2}{|c|}{ Puerto Tejada } & Cauca & $20 \%$ & $5 \%$ \\
\hline \multicolumn{2}{|c|}{$\frac{\text { Valle del Cauca }}{\text { Palmira }}$} & Valle del Cauca & $16,4 \%$ & $2,4 \%$ \\
\hline \multicolumn{2}{|c|}{ Pasto } & Nariño & $8,5 \%$ & $0 \%$ \\
\hline
\end{tabular}


Continuación Cuadro 19.

\begin{tabular}{|c|c|c|c|c|}
\hline $\begin{array}{c}\begin{array}{c}\text { Región } \\
\text { Departamento }\end{array} \\
\text { Municipio } \\
\text { Localidad }\end{array}$ & $\begin{array}{c}\text { Autor o } \\
\text { Referencia } \\
\text { Institución }\end{array}$ & $\begin{array}{c}\text { Población } \\
n \\
\text { individuos }\end{array}$ & $\begin{array}{c}\text { Prevalencia } \\
\text { Infección } \\
\%\end{array}$ & $\begin{array}{c}\text { Prevalencia } \\
\text { Portadores } \\
\text { AgsHB } \\
\%\end{array}$ \\
\hline & & \multicolumn{3}{|c|}{ Area de trabajo } \\
\hline & & $\begin{array}{l}\text { Medicina general } \\
\text { Auxiliares de }\end{array}$ & $15,2 \%$ & $7,7 \%$ \\
\hline & & enfermería & $20,5 \%$ & $2,0 \%$ \\
\hline & & Personal de aseo & $17,7 \%$ & $1,4 \%$ \\
\hline Cali & $\begin{array}{c}\text { E. Duque } \\
\text { HU del Valle } \\
(96)\end{array}$ & $\begin{array}{l}\text { Personal de } \\
\text { salud } \\
n=209\end{array}$ & $\begin{array}{c}\text { Global: } 26,3 \% \\
\text { Médicos: } \\
30,8 \% \\
\text { Odontólogos: } \\
21 \% \\
\text { Bacteriólogos: } \\
16,2 \%\end{array}$ & $0,5 \%$ \\
\hline
\end{tabular}

Cuadro 20. ESTUDIOS SOBRE HEPATITIS B EN EL SECTOR SALUD Estudios por Regiones / Departamentos

\begin{tabular}{|c|c|c|c|c|}
\hline $\begin{array}{c}\begin{array}{c}\text { Región } \\
\text { Departamento }\end{array} \\
\text { Municipio } \\
\text { Localidad }\end{array}$ & $\begin{array}{l}\text { Autor o } \\
\text { Referencia } \\
\text { Institución }\end{array}$ & $\begin{array}{c}\text { Población } \\
n \\
\text { individuos }\end{array}$ & $\begin{array}{c}\text { Prevalencia } \\
\text { Infección } \\
\%\end{array}$ & $\begin{array}{c}\text { Prevalencia } \\
\text { Portadores } \\
\text { AgsHB } \\
\%\end{array}$ \\
\hline \multicolumn{5}{|c|}{ COSTA ATLANTICA } \\
\hline $\begin{array}{l}\text { Regional } \\
\text { Atlántico } \\
\text { Magdalena } \\
\text { Cesar } \\
\text { Bolivar }\end{array}$ & $\begin{array}{l}\text { A Haag } \\
\text { CETI } \\
\text { DASALUD } \\
\text { Trabajadores de } \\
\text { salud } \\
(97)\end{array}$ & $\begin{array}{c}\text { Región } \\
\text { Atlántico } \\
n=1622 \\
\text { Magdalena } \\
n=1244 \\
\text { Cesar } \\
n=584 \\
\text { Bolívar } \\
n=777\end{array}$ & $\begin{array}{c}\text { Global: } 21 \% \\
12 \% \\
38 \% \\
19 \% \\
21 \%\end{array}$ & $\begin{array}{c}\text { Global: } 5 \% \\
3,0 \% \\
8,27 \% \\
5,8 \% \\
2,8 \%\end{array}$ \\
\hline $\begin{array}{c}\text { Bolivar } \\
\text { Cartagena }\end{array}$ & $\begin{array}{l}\text { D Urbina } \\
\text { H. Universitario } \\
(61)\end{array}$ & $\begin{array}{c}\text { Personal del } \\
\text { Hospital } \\
n=94\end{array}$ & \multicolumn{2}{|c|}{$\begin{array}{c}\text { Portadores } \\
\text { Infectología: } 21,4 \% \\
\text { Hemodiálisis: } 40 \% \\
\text { Enfermeras: } 16,6 \% \\
\text { Auxiliares enfermería: } 22,2 \%\end{array}$} \\
\hline$\frac{\text { Cesar }}{\text { Valledupar }}$ & $\begin{array}{l}\text { W Ortega } \\
\text { H. Rosario } \\
\text { Pumarejo de } \\
\text { López y } \\
\text { DASALUC } \\
(98)\end{array}$ & $\begin{array}{c}\text { Trabajadores de } \\
\text { salud } \\
n=293\end{array}$ & \multicolumn{2}{|c|}{$\begin{array}{c}\text { Cirujanos: } 50 \% \text { Enfección } \\
\text { Médicos generales: } 31 \% \\
\text { Aseadoras: } 44 \% \\
\text { Odontólogos: } 100 \% \\
\text { Servicios } \\
\text { Urgencias: } 40 \% \\
\text { Clínicas Quirúrgicas: } 62 \% \\
\text { Ginecología y Pediatría: } 48 \% \\
\text { Odontología: } 100 \%\end{array}$} \\
\hline
\end{tabular}


Continuación Cuadro 20.

\begin{tabular}{|c|c|c|c|c|}
\hline $\begin{array}{c}\text { Región } \\
\text { Departamento } \\
\text { Municipio } \\
\text { Localidad }\end{array}$ & $\begin{array}{l}\text { Autor o } \\
\text { Referencia } \\
\text { Institución }\end{array}$ & $\begin{array}{l}\text { Población } \\
n \\
\text { individuos }\end{array}$ & $\begin{array}{c}\text { Prevalencia } \\
\text { Infección } \\
\%\end{array}$ & $\begin{array}{c}\text { Prevalencia } \\
\text { Portadores } \\
\text { AgsHB } \\
\%\end{array}$ \\
\hline$\frac{\text { La Guajira }}{\text { Alta Guajira }}$ & $\begin{array}{l}\text { H Cuevas } \\
\text { Hospital } \\
\text { Nazareth y } \\
\text { centros de salud } \\
(99)\end{array}$ & $\begin{array}{c}\text { Trabajadores de } \\
\text { salud } \\
n=81\end{array}$ & $9,87 \%$ & $\begin{array}{c}1,2 \% \\
\text { ( Infección } \\
\text { temprana } \\
+ \text { portadores: } \\
6,1 \% \text { ) }\end{array}$ \\
\hline
\end{tabular}

Cuadro 21. Patrón geográfico de la prevalencia de hepatitis $\mathrm{B}$ y mecanismos de transmisión. Espinal C, modificado de WHO, october 1996 ( 12 ).

\begin{tabular}{|c|c|c|c|}
\hline $\begin{array}{l}\text { Prevalencia } \\
\text { marcadores } \\
\text { VHB } \\
\text { Transmisión }\end{array}$ & $\begin{array}{c}\text { Baja } \\
\text { endemicidad }\end{array}$ & $\begin{array}{l}\text { Mediana } \\
\text { endemicidad }\end{array}$ & Alta endemicidad \\
\hline $\begin{array}{c}\text { Ags } \mathrm{HB} \\
\text { (Portadores) }\end{array}$ & $<2 \%$ & $2-7 \%$ & $>8 \%$ \\
\hline Infección & $<15 \%$ & $15-45 \%$ & $>45 \%$ \\
\hline Perinatal & Ocasional & Esporádica & $\begin{array}{l}\text { Común. Altas tasas en } \\
\text { menores de } 1 \text { año }\end{array}$ \\
\hline Horizontal & Ocasional & Esporádica & $\begin{array}{l}\text { Común. Altas tasas en } \\
\text { menores de } 5 \text { y } 10 \text { años }\end{array}$ \\
\hline Sexual & Frecuente & Frecuente & Esporádica \\
\hline Drogas I.V. & Frecuente & Ocasional & Ocasional \\
\hline \multicolumn{4}{|c|}{ DISTRIBUCION GEOGRAFICA } \\
\hline & $\begin{array}{c}\text { Estados Unidos } \\
\text { Europa } \\
\text { Occidental }\end{array}$ & $\begin{array}{c}\text { Europa del Este } \\
\text { Rusia } \\
\text { Medio Oriente } \\
\text { Sur América: } \\
\text { Brasil, Perú, } \\
\text { Colombia }\end{array}$ & $\begin{array}{c}\text { Sudeste Asiático } \\
\text { Africa Tropical } \\
\text { Islas del Pacífico } \\
\text { Medio Oriente } \\
\text { Sur América: } \\
\text { Amazonia de Colombia, } \\
\text { Perú, Venezuela y Brasil } \\
\text { Area limítrofe } \\
\text { Venezuela-Colombia } \\
\text { Regiones del Pacífico, } \\
\text { centro-oriente } \\
\text { y norte de Colombia }\end{array}$ \\
\hline
\end{tabular}


El cuadro 21 describe la distribución geográfica de la prevalencia de hepatitis B y sus mecanismos de transmisión predominantes.

El mapa de riesgo (figura 1) identifica los departamentos con alta y mediana endemicidad para el VHB, con base en los resultados descritos en los cuadros anteriores, los patrones epidemiológicos de infección y de portadores del virus $B$ descritos en el cuadro 21 , y la presencia simultánea del virus Delta.

Las figuras 2 y 3 muestran los resultados de la estratificación por riesgo de la ciudad de Cali para hepatocarcinoma, cirrosis e infección por el virus de la hepatitis $B$.

\section{Encuesta Nacional de Salud, 1977-1980}

La prevalencia de antígeno de superficie del VHB en Colombia fue establecida en 1980 mediante una encuesta seroepidemiológica realizada por el Instituto Nacional de Salud, que incluyó una muestra representativa de 10.968 individuos, representativa de una población de 12 '800.430 personas. El estudio se realizó en los departamentos comprendidos en las regiones oriental, central y pacífica (13).

La tasa nacional representativa de portadores del VHB fue de $4,7 \%$. Un total de 611.828 portadores fueron detectados. De este total, 267.812 eran mujeres en edad fértil. En

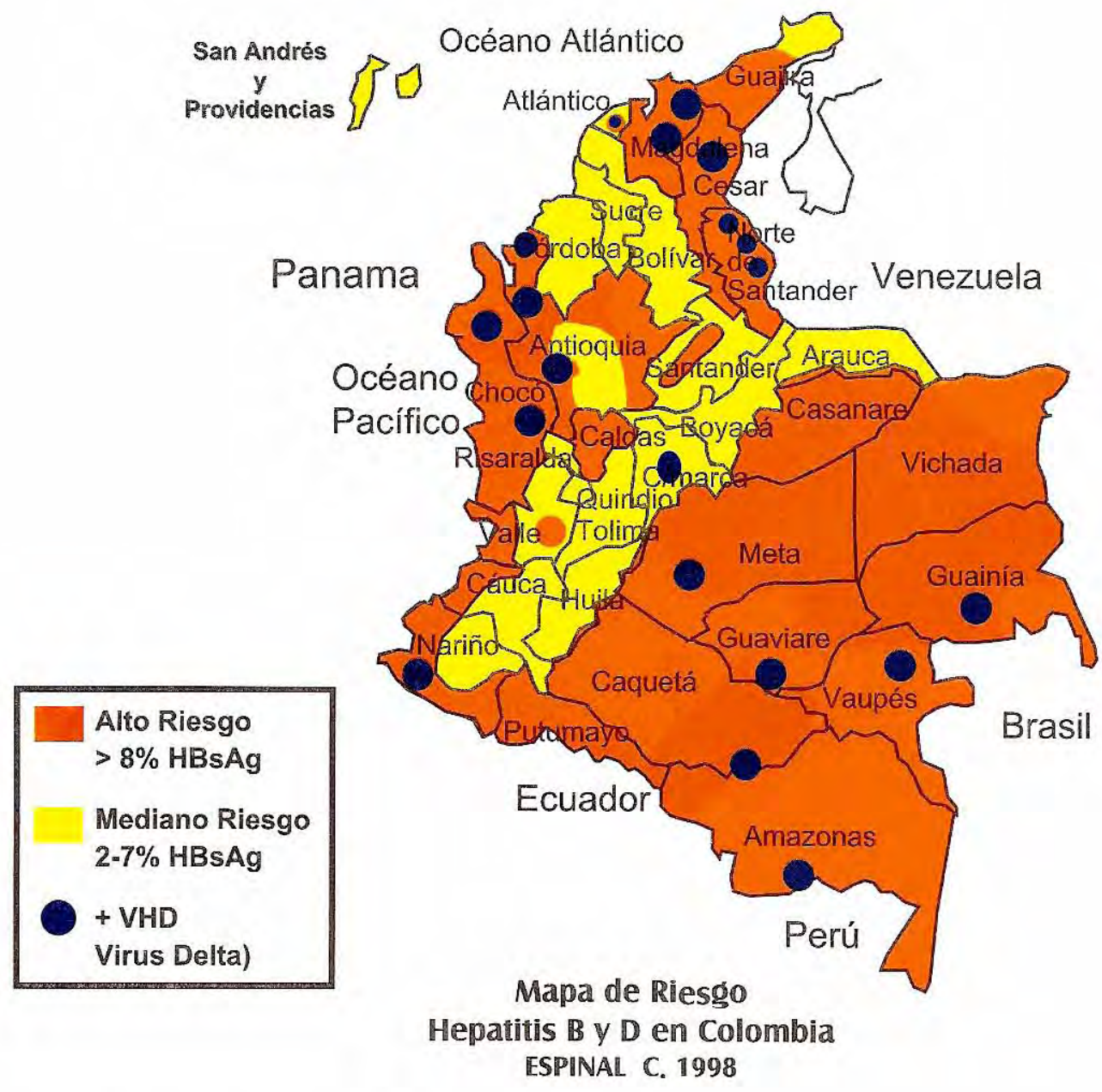

Figura 1. Mapa de riesgo de la hepatitis B y D en Colombia. 


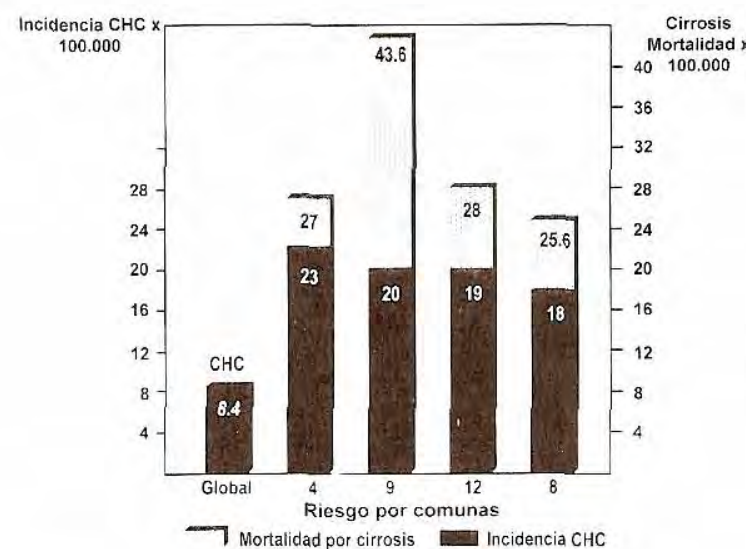

J.H. Rojas., Secretaria de Salud, Cali 1996 (51)

Figura 2. Carcinoma hepatocelular $(\mathrm{CHC})$ y cirrosis, Cali, Colombia, 1994. menores de 15 años, se registraron 177.503 niños y, en el grupo de 10-19 años, se detectaron 170.433 portadores adolescentes.

En la región oriental (Norte de Santander, Santander, Boyacá, Cundinamarca y Meta), la tasa de portadores fue de $2,8 \%$, para un total de 112.350 personas portadoras del VHB.

La región central (Antioquia, Caldas, Tolima y Huila) informó una tasa de $7,1 \%$ con una prevalencia de $11,7 \%$ en niños menores de 4 años de edad. El total de portadores detectados fue de 372.469 personas.

Para la región pacífica (Chocó, Valle del Cauca, Cauca y Nariño), la tasa fue de $3,5 \%$ con 126.993 portadores del antígeno de superficie.

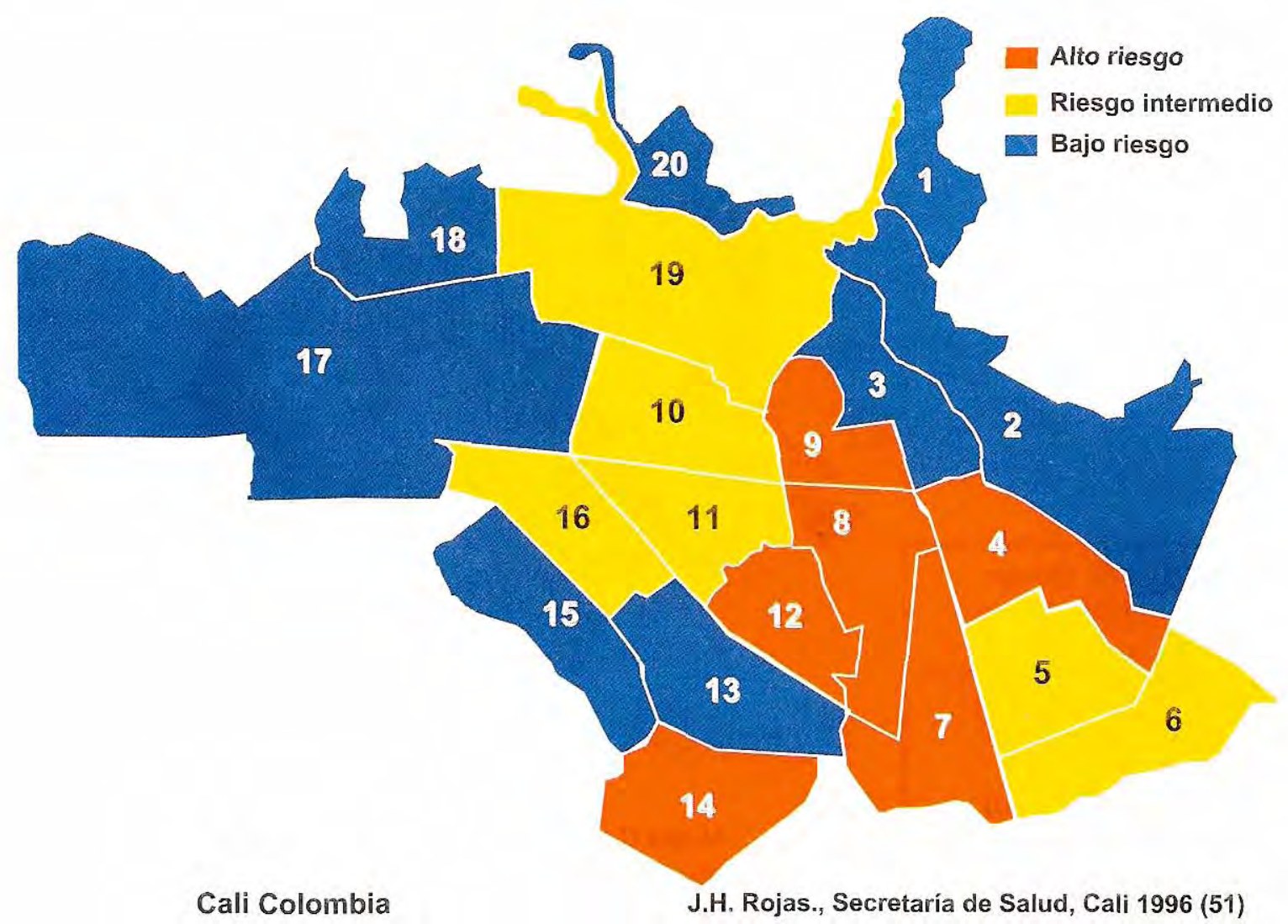

Figura 3. Estratificación de riesgo por comunas para carcinoma hepatocelular, cirrosis y hepatitis B Cali, Colombia. 


\section{Región Amazonia y Orinoquia}

Amazonia: Amazonas, Caquetá y Putumayo.

Orinoquia: Arauca, Casanare, Guainía, Guaviare, Meta, Vaupés y Vichada

Cuadros 1, 2, 12, 13, 14, 15, 17.

Las regiones de la Amazonia y Orinoquia tradicionalmente han sido identificadas como zonas de alta endemicidad, como se aprecia en el mapa 1. En los estudios sobre poblaciones, las tasas de infección superan el $50 \%$ en población general y son superiores al $8 \%$ las prevalencias de portadores del AgsHB. En niños menores de 15 años, se observan prevalencias de infección mayores del $50 \%$, y de portadores superiores a $8-10 \%$. Incluso en niños menores de 9 años se reportan tasas de portadores hasta de $15 \%$ (cuadros 1,2).

En los departamentos del Caquetá, Arauca, Casanare y Vichada, se observan altas tasas de portadores en bancos de sangre. Vichada informa para 1995 una prevalencia de AgsHB de $8,5 \%$, Arauca $1,9 \%$ y $12,8 \%$ de anti-core en 1997, Guaviare 3,3\%. En 1994 Caquetá informa $3,3 \%$, Casanare $5,5 \%$, Guainía 4,9\%, Meta $2,1 \%$ y Vaupés $4,6 \%$ (cuadro 12 ).

Las prevalencias de AgsHB observadas en las poblaciones indígenas confirman la elevada endemicidad de la hepatitis $B$ en la región (cuadros 13,14).

En el departamento del Meta, se observan grupos indígenas con tasas de infección entre 38 y $90 \%$ y de portadores entre 10 y $33 \%$ de las poblaciones estudiadas (cuadro 14). El departamento de Meta fue incluido en la región oriental del Estudio Nacional de Salud realizado por el INS en el cual se clasificó la región con una tasa de $2,8 \%$ de portadores, considerada como nivel de endemicidad intermedia (13). Sin embargo, la información en comunidades indígenas, la presencia del VHD en el área de La Macarena y del río Guejar (C. Espinal, Hospital de La Samaritana), la positividad en bancos de sangre y los altos niveles de prevalencia en los Departamentos vecinos (mapa 1), definen una tendencia hacia la alta endemicidad.
Con relación al virus delta, en los estudios analizados para las dos regiones, se reportan casos comprobados por anatomía patológica de pacientes fallecidos durante las epidemias de hepatitis fulminante por VHD. En Vaupés y Guaviare (cuadro 2) se observan prevalencias de anti-delta hasta de $33 \%$ en menores de 4 años de edad y de $23 \%$ en Las Charras.

\section{Región centro oriente}

Departamentos: Distrito de Santa Fe de Bogotá, Cundinamarca, Boyacá, Huila, Norte de Santander, Santander y Tolima.

Cuadros: 2, 3, 4, 5, 12, 13, 14, 15, 16, 17.

En la región centro-oriente, especialmente en Santa Fe de Bogotá y Cundinamarca, los estudios han sido realizados en grupos de riesgo, pacientes hospitalizados con patologías de riesgo para hepatitis $B$, pacientes con diagnóstico de hepatitis, maternas con atención de parto institucional, personal de salud y comunidades indígenas en los departamentos de Santander y Norte de Santander. Con la reducida información obtenida en grupos de población para estos departamentos, se dificulta una clasificación epidemiológica de riesgo y niveles de endemicidad.

Sobre los departamentos de Boyacá y Huila, no se encontraron estudios de población ni de grupos específicos de riesgo. El Estudio Nacional de Salud realizado por el INS incluyó al departamento de boyacá en la región oriental, con una tasa mediana global de endemicidad del $2,8 \%$. Huila fue incluido en el mismo estudio en la región central, cuya tasa de mediana endemicidad fue de 7,1\% (13). En bancos de sangre, para 1995, la positividad de AgsHB fue del $0,9 \%$ y $0,5 \%$ respectivamente, cuando el promedio nacional fue de $0,9 \%$. Ambos departamentos se consideran de riesgo intermedio para la hepatitis $B$.

Para Santa Fe de Bogotá y Cundinamarca, los estudios se concentran sobre grupos específicos y únicamente se tiene la información por regiones del Estudio Nacional de Salud. En el Estudio se reporta una endemicidad intermedia con una tasa promedio de $7,1 \%$ de portadores 
para la región central, con tasas de $11,7 \%$ en niños entre los 0-4 años de edad, donde ha sido incluida Cundinamarca (13).

La información obtenida para Santa $\mathrm{Fe}$ de Bogotá y Cundinamarca en los diversos grupos estudiados demuestran un patrón primordialmente bajo e intermedio, con excepción de algunos grupos especiales como los niños con leucemia y los pacientes con hepatitis aguda y crónica, en los cuales se esperan proporciones elevadas de hepatitis $B$ (cuadros 2, 3, 4).

Los resultados en maternas atendidas en hospitales de Santa $\mathrm{Fe}$ de Bogotá muestran proporciones de AgsHB que varían desde 0,1 a $4,4 \%$. Solo un estudio presentó proporciones muy elevadas de $9,5 \%$ en el Instituto Materno Infantil (cuadros 2, 3). En conjunto, se han estudiado 2.443 maternas para una prevalencia media de AgsHB de $3,0 \%$, incluyendo el dato referenciado anteriormente.

Los estudios sobre personal de salud en Santa Fe de Bogotá confirman estas conclusiones, a pesar de ser grupos de mayor riesgo para el VHB (cuadros 15, 16, 17). La excepción es el estudio realizado en el Hospital San Juan de Dios por J. Saravia y colaboradores, quienes informan una prevalencia de $17,6 \%$ de AgsHB.

El estudio de Ljunggren y col. (cuadro 3) muestra una positividad para anti-delta de $6 \%$ en los pacientes del Hospital San Juan de Dios; sin embargo, no se precisa la procedencia de los pacientes positivos, quienes tenían hepatitis como diagnóstico presuntivo.

En el departamento del Tolima se informan dos estudios realizados en el municipio de Honda por el Grupo de Epidemiología del Instituto Nacional de Salud (cuadro 4). En maternas se detectó una prevalencia de AgsHB de $4,4 \%$ y en los internos de la cárcel de $22 \%$. Los datos de banco de sangre para 1995 muestran una positividad de $1,1 \%$ cuando el promedio nacional fue de $0,9 \%$ para el mismo año. El Estudio Nacional de Salud incluyó el departamento dentro de la región central cuya tasa de $7,1 \%$ lo clasifica de endemicidad intermedia, a pesar del informe de prevalencias elevadas en los menores de 4 años para la misma región (13). En los estudios sobre prevalencias en el Instituto de Seguros Sociales (ISS), Cundinamarca y Tolima formaron parte de los departamentos agrupados en la región andina, cuya tasa de infección fue de $24,3 \%$ y de portadores de $1,2 \%$ (cuadro 17 ).

Norte de Santander ha sido un departamento considerado de alto riesgo para hepatitis $\mathrm{B}$ y delta. Elevadas prevalencias globales y por edades de ambos virus se describen en el cuadro 4 en las poblaciones de Gabarra, Río de Oro y Tibú. Igualmente, se informa para 1995 una prevalencia de $3,9 \%$ en bancos de sangre y en las comunidades indígenas de los Motilones y los Tunebos, tasas de infección y de portadores de $65 \%$ y $15 \%$ y de $25 \%$ y $3 \%$ respectivamente (cuadros 12, 13, 14).

Santander se incluyó en la región central en el Estudio Nacional de Salud con una tasa promedio de $2,8 \%$ de prevalencia intermedia (13). Para 1994, la prevalencia de AgsHB en bancos de sangre fue de $1,6 \%$, superior al promedio nacional del 1,0\% para el mismo año. En el Hospital de Ecopetrol en Barrancabermeja la proporción de portadores en donantes de sangre voluntarios fue de 1,6\% (cuadro 5). En población indígena, la comunidad Guane presenta tasas de infección de $72 \%$ y $36 \%$ de portadores, compatibles con alta endemicidad. Santander esta incluido en el grupo de la región andina del estudio multicéntrico del ISS en personal de salud cuya tasa de prevalencia fue de $1,2 \%$.

\section{Región Occidente}

Departamentos: Antioquia, Caldas, Cauca, Chocó, Nariño, Quindío, Risaralda y Valle del Cauca.

Cuadros 5, 6, 7, 8, 12, 13, 14, 18, 19

El Estudio Nacional de Salud incluyó a los departamentos de Antioquia y Caldas en la región central cuya tasa global de prevalencia de $7,1 \%$ los clasifica como de endemicidad intermedia; las tasas de este estudio para los niños menores de 4 años y para el grupo de 1014 años fueron de $11,7 \%$ y $9,8 \%$, respectivamente. Estas son tasas compatibles con áreas de alto riesgo (13). 
Cauca, Chocó, Nariño y Valle del Cauca fueron incluidos en el mismo estudio en la región pacífica con tasas intermedias de 3,5\% (13).

El perfil para Antioquia, con base en los resultados obtenidos en diversas poblaciones muestra una gran variabilidad en las proporciones de infección y portadores. Podría clasificarse globalmente como un patrón elevado con municipios de alta prevalencia en todas las regiones del departamento, y algunos municipios con prevalencias intermedias y bajas. El VHD hasta el momento ha sido notificado en la región de Urabá (cuadros 5, 6, 18). En 1996, 59 municipios $(47,2 \%)$ tenían tasas de incidencia superiores al promedio departamental de $3,1 \mathrm{x}$ 100.000 habitantes y 14 de ellos habían sido considerados de alta endemia en el Estudio Nacional de Salud. Adicionalmente, 24 municipios (19\%) presentaron tasas que superan ese promedio en más de $300 \%$ (cuadro 6). La prevalencia en bancos de sangre para 1994 fue de $2,3 \%$, elevada si se consideran los adecuados controles para la donación de sangre en individuos de riesgo en los servicios de salud del departamento.

La información obtenida para el departamento del Chocó lo clasifica en un departamento de alta endemicidad por sus elevadas tasas de infección y portadores y presencia del virus delta (cuadros 7, 8, 13, 14).

El Valle del Cauca, Cauca y Nariño pueden globalmente registrarse como departamentos de mediana endemicidad, con áreas o regiones de alto riesgo principalmente hacia los municipios de la costa del Pacífico (cuadros 7, 8, 14, 17, 19).

\section{Costa atiántica}

Departamentos: Atlántico, Bolívar, Cesar, Córdoba, La Guajira, Magdalena, San Andrés y Sucre.

Cuadros: 8, 9, 10, 11, 12, 13, 14, 17, 20.

Los departamentos de Atlántico y Bolívar presentan tasas de infección y portadores compatibles con una endemicidad intermedia. En algunos estudios en Atlántico y, particular- mente en Barranquilla, se informan tasas que superan el $8 \%$ de portadores, en donantes de sangre se llega a $5 \%$ y se reporta una positividad elevada para el VHD, con alto riesgo de ocasionar casos o brotes de hepatitis fulminante (cuadros 8, 9, 20). En un estudio realizado en 1989 en 240 donantes de sangre en el Hospital Universitario de Cartagena, Bolívar, la prevalencia de AgsHB fue de 2,0\%. Los resultados en el personal de salud son compatibles con áreas de transmisión intermedia (cuadros 9, 12, 20).

Cesar ha sido considerado como un departamento de alto riesgo para los virus $B$ y $D$ debido a sus elevadas tasas de infección y de portadores en poblaciones indígenas, personal de salud y grupos laborales de la comunidad. El virus delta ocasiona epidemias de hepatitis fulminante en algunas comunidades. La tasa global de incidencia de hepatitis $B$ es de $40 \times 100.000$ habitantes y la prevalencia en bancos de sangre para 1994 y 1995 fue de 2,4\% y 2,6\% respectivamente. En el banco de sangre de la Cruz Roja se reportó en 1995 una tasa de $2,9 \%$ (cuaros 9 , $10,12,13,14,20)$.

La Guajira es un departamento con endemicidad y riesgo intermedio de acuerdo a los informes en población general y comunidades indígenas (cuadros 10, 13, 14, 20). En bancos de sangre, para 1995, mostró una prevalencia de $2,1 \%$ de AgsHB (cuadro 12).

El Plan nacional de control de las hepatitis $B$ y $D$ del Ministerio de Salud clasificó a la parte baja e intermedia del departamento entre las zonas de alto riesgo, especialmente en Riohacha, área rural de las estribaciones de la Sierra Nevada de Santa Marta y San Juan del Cesar, donde se localizan las poblaciones indígenas de los Arhuacos, Koguis y Arzarios (Control de las hepatitis B Y D en Colombia. Santa Fe de Bogotá: Ministerio de Salud, Instituto Nacional de Salud, 1992)).

El departamento del Magdalena es un departamento de alto riesgo y endemicidad para los virus $B$ y $D$. En el municipio de Ciénaga y su área rural se han detectado elevadas prevalencias de portadores del AgsHB, aun en niños menores de 1 año y menores de 10 años. El 
VHD presenta igualmente altas proporciones por edades y localidades y ha ocasionado severas epidemias de hepatitis fulminante con alta mortalidad (cuadros 10, 11, 20). En bancos de sangre, se reportó para 1995 un 4,3\% de positividad del AgsHB y $13,8 \%$ de anti-core en 1997 , tres veces más del promedio nacional para el mismo año (cuadro 12). En los resultados sobre personal de salud, se registró igualmente la tasa más elevada de la región, con un $8,27 \%$ de portadores (cuadro 20).

San Andrés y Providencia tienen indicadores de prevalencia intermedia. En el banco de sangre de San Andrés reportó una tasa de portadores de 1,9\% para 1995 (cuadro 12). En Providencia, en un estudio sobre 44 individuos, se demostró una tasa de portadores de $5 \%$ (cuadro 14).

\section{Distribución del virus Delta}

La figura 1 describe la amplia circulación del virus delta en Colombia, asociada con la presencia de brotes de hepatitis fulminante en la mayoría de los departamentos registrados. Su distribución geográfica coincide con los departamentos clasificados como de alto riesgo por las elevadas tasas de portadores del VHB.

\section{Carcinoma hepatocelular, cirrosis e incidencia de la infección por el VHB}

En Cali, JH Rojas de la Secretaría de Salud realizó la más importante investigación hasta el momento sobre hepatoma, cirrosis y hepatitis B entre 1987 y 1996, con el fin de determinar el comportamiento y posibles asociaciones entre estas variables en las comunas de la ciudad (figuras 2 y 3). Para 1988, la tasa de incidencia global de hepatocarcinoma fue de 1,01 x 100.000 habitantes, triplicándose para 1994 hasta $3,28 \times 100.000$ habitantes.

Las tasas de hepatoma por edades mostraron incidencias de 23,3 x 100.000 para el grupo de 50-54 años, 41,7 para el de 60-64 años, 96 para el de 70-74 años y $180 \times 100.000$ para el de 75 79 años.

La tasa promedio por comunas para 1994 fue de $8,44 \times 100.000$ habitantes. Las tasas por comunas presentaron incidencias globales de $23 \times 100.000$ para la comuna $4,20 \times 100.000$ para la $9,19 \times 100.000$ para la comuna $12,18 \times$ 100.000 para la 8 y $14 \times 100.000$ para la comuna 4.

En 1994, se reportaron en Cali 106 muertes por cirrosis y 61 nuevos casos de hepatoma. El $67 \%$ de los casos de hepatoma del adulto estaban asociados con cirrosis. Las más altas incidencias de hepatoma y mortalidad por cirrosis coincidieron en las comunas 8,9 y 12 . Igualmente coincidentes fueron los resultados de la incidencia de hepatitis $B$, identificando a las comunas $4,7,8,9$ y 12 como las de mayor riesgo.

El análisis permitió establecer que las comunas $4,8,9,10$ y 7 correspondían a las comunas de alto riesgo para la infección por el virus de la hepatitis B y sus complicaciones como el carcinoma hepatocelular y cirrosis. El estudio permite clasificar a Cali como un municipio de alto riesgo para la infección por VHB (figuras 2 y 3).

\section{Discusión}

La epidemiología de la hepatitis B presenta grandes variaciones en los patrones de infección y portadores de acuerdo con la diversidad de las regiones geográficas, el tipo de población y sus factores de riesgo asociados, el estado socioeconómico y cultural y el adecuado acceso a servicios de salud.

Bajo estas circunstancias, la obtención de información relevante necesaria para conformar el perfil epidemiológico de la hepatitis $B$ y $D$, se dificulta en los países en desarrollo como Colombia, debido a los deficientes sistemas de vigilancia epidemiológica y, por consiguiente, a unos inadecuados e insuficientes sistemas de registro y análisis. El laboratorio para el diagnóstico etiológico de las hepatitis y para estudios serológicos de seroprevalencia es igualmente una seria limitante en muchas regiones, impidiendo la obtención de información fidedigna sobre los indicadores que evidencien las poblaciones en riesgo.

En Colombia, existe un número importante de trabajos y publicaciones sobre la hepatitis $B$ cuya limitante, en su gran mayoría, es el 
reducido tamaño de las muestras poblacionales en cada región o departamento, dificultando la significancia de la información. Sin embargo, de acuerdo con los conceptos señalados por el Grupo de Trabajo sobre Inmunización en Hepatitis B de la Organización Mundial de la Salud (OMS), la información obtenida de pequeños estudios en una región y de regiones vecinas, puede ser suficiente para determinar la epidemiología de la hepatitis B y tomar las decisiones pertinentes para el desarrollo de los programas de vacunación (1).

A pesar de las dificultades para recopilar la información científica publicada en revistas locales como ha sido el caso de la presente revisión, se tienen publicaciones de estudios realizados en la gran mayoría de los departamentos, lo cual permiten una aproximación a la estratificación por riesgo y niveles de endemicidad (figura 1).

La información obtenida en los bancos de sangre a nivel nacional presenta un importante subregistro debido a que la población donante es mayor de 18 años de edad y los enfermos o individuos con factores de riesgo están excluidos en su gran mayoría de la donación. El registro, además, se concentra en las áreas urbanas donde existen los recursos adecuados de laboratorio. A pesar de estas limitantes, las prevalencias reportadas por los departamentos contribuyen a la clasificación de riesgo, cuando tienen tasas elevadas que superan el promedio nacional (cuadro 12). En un interesante estudio recientemente publicado por $\mathrm{G}$ Schmunis y col. de la OPS, sobre riesgo de enfermedades infecciosas transmitidas por transfusiones de sangre en América Central y Suramérica (100), se destaca como en 1993 y 1994 solo 3 de los 12 países analizados evaluaban todos los donantes de sangre para el virus de la hepatitis B. El estudio indica que en Colombia para 1993 entre 352.316 donantes en Colombia se podrían haber inducido 8 infecciones por $\mathrm{VIH}, 32$ por VHB, 2.364 por VHC y 875 por T. cruzi. Estos cálculos para hepatitis $B$ están basados en una cobertura de $98,3 \%$ de los donantes (proporción de individuos a quienes se les realizó la prueba serológica para hepatitis $B$ entre el total de donantes) y una prevalencia de $7 \times 1.000$. De acuerdo con este informe la transmisión del VHB en Colombia a través de las transfusiones de sangre tiene un adecuado control mediante la oportuna evaluación serológica de los donantes en los bancos de sangre.

En los mapas de riesgo elaborados por la OMS para la infección por el virus $\mathrm{B}$, Colombia se clasifica como país de riesgo bajo o intermedio (12). Los resultados expuestos demuestran que Colombia posee extensas regiones de alta y mediana endemicidad para el virus $B$, con tasas de portadores y de infección que comprometen a la población infantil, adolescentes y adultos jóvenes. El mapa de riesgo por departamentos presenta una visión de la epidemiología regional de las hepatitis $B$ y $D$, aunque existe una gran diversidad, aun en los mismos departamentos, sobre las prevalencias de portadores del virus $B$.

La transmisión en las áreas de alto riesgo está asociada principalmente con el contacto entre la madre infectada y el niño durante el período del parto (transmisión perinatal y vertical) y por el continuo y cercano contacto entre niños, o entre niños y sus padres o parientes cercanos portadores (transmisión horizontal). En las áreas de endemicidad intermedia y baja, son más afectados los jóvenes y adultos y el mecanismo principal de transmisión parece ser la vía sexual (cuadro 21)

Colombia ha sido el primer país en Latinoamerica en incluir la vacunación universal de los niños menores de un año y recién nacidos contra la hepatitis B. El perfil epidemiológico presentado en el mapa de riesgo y en la información por departamentos, reafirma la política de vacunación universal de la infancia recomendada por OMS para los países con endemicidad alta e intermedia, establecida en el país desde 1992, a través del Programa Ampliado de Inmunizaciones (PAI) del Ministerio de Salud. La inmunización contra la hepatitis $B$ se extiende actualmente a todos los niños menores de 5 años; en las áreas de alto riesgo, cubre hasta los menores de 10 años de edad.

Debido al patrón de transmisión presentado en el cuadro 21 en el cual la transmisión por vía 
sexual es de elevada frecuencia en nuestras regiones, la vacunación de los adolescentes representa una estrategia complementaria que, en términos de efectividad, tiene un rápido impacto en la incidencia de la hepatitis B y debería ser considerada por las autoridades de salud y las diferentes institucionres prestadoras de salud de Colombia. Igualmente, la vacunación contra la hepatitis $\mathrm{B}$ debe formar parte de los esquemas de inmunización del adulto, principalmente en el grupo entre los 19 y los 45 años de edad donde se incrementa notoriamente el riesgo de enfermedades de transmisión sexual.

El impacto del programa de vacunación del PAI contra la hepatitis $B$ ha sido determinado en un estudio preliminar en el área rural del municipio de Ciénaga, departamento del Magdalena, área de alta endemicidad para el VHB y VHD. La evaluación realizada en esta zona demostró una reducción en la tasa de infección de $75 \%$ en 1985 a $10 \%$ en 1997 , y de portadores de $10 \%$ a $0 \%$ para una efectividad del programa del $87 \%$ y $100 \%$, respectivamente (101). Esta evaluación de la efectividad del programa debe promover estudios en otras regiones endémicas, mediante la determinación de los indicadores fundamentales para la elaboración del perfil epidemiológico de la hepatitis $\mathrm{B}$, el registro adecuado y sistemático de la vacunación y el acceso oportuno a la tecnología diagnóstica, con el fin de medir el impacto de la vacunación en poblaciones y grupos de edad específicos.

En la medida en que se incrementan los niveles de coberturas de vacunación contra la hepatitis $B$, su epidemiología podría modificarse en algunos indicadores básicos. La inmunización puede cambiar la distribución relativa por edades, presentando una incidencia más elevada en las edades mayores no vacunadas. Adicionalmente, aunque la vacuna tiene una eficacia superior a $90 \%$, con las altas coberturas de vacunación la proporción de casos podría aumentar en las poblaciones vacunadas. De este modo, el número absoluto de casos se reduce pero la proporción de casos en vacunados se incrementa (102). Algunas áreas pueden tener coberturas bajas sosteniendo tasas importantes de infección y portadores, en las cuales pueden ocurrir epidemias, especialmente si hay circulación simultánea del virus delta.

Otra de las posibles consecuencias de los programas intensificados contra la hepatitis $B$ es la aparición de mutantes del virus $B$, en poblaciones con alta presión inmunológica sobre el VHB (103). Estas consideraciones implican la necesidad de un programa de vigilancia epidemiológica que permita la evaluación continua de estas variables y detecte tempranamente los cambios en los patrones o indicadores que miden el impacto de los programas de inmunización.

El cáncer primario de hígado más frecuente es el carcinoma hepatocelular, actualmente asociado a la infección crónica de los virus de las hepatitis B y C. Su distribución geográfica se concentra principalmente en el sudoeste de Asia y en el sub-Sahara de Africa, áreas de elevada endemicidad para la hepatitis B. De acuerdo con las tasas de incidencia en el mundo, Colombia presenta niveles intermedios para el carcinoma hepatocelular con tasas entre 3 y 10 casos por 100.000 habitantes (104).

El estudio realizado por JH Rojas (51) en la Secretaría de Salud de Cali demuestra la importancia de la vigilancia epidemiológica y los procesos de estratificación por riesgos para una enfermedad compleja como la hepatitis $B$ y sus serias complicaciones crónicas. Las altas tasas por comunas comparadas con la tasa global de carcinoma hepatocelular en Cali, y sus coincidentes elevadas incidencias de cirrosis y de infección por el virus de la hepatitis B, establecen sectores de población que requieren una intensificación de las actividades de diagnóstico y prevención de la hepatitis B, incluyendo la educación comunitaria como parte integral del programa de salud. En estas comunas de alto y mediano riesgo, la vacunación contra la hepatitis $\mathrm{B}$ debería extenderse a la población de adolescentes y adultos jóvenes con el fin de reducir la población de susceptibles y las elevadas tasas de infección y 
carcinoma hepatocelular. Estos resultados demuestran el importante peso de la hepatitis $B$ en la carga de las enfermedades en las regiones endémicas; por consiguiente, el análisis de estas variables debería extenderse a las regiones y departamentos identificadas en el mapa. No existe, hasta el momento, un estudio nacional sobre hepatocarcinoma primario y distribución geográfica de la hepatitis $B$ en el país, aunque se encuentran los informes globales de este tipo de cáncer en las estadísticas nacionales.

Aun no se conocen bien los mecanismos por los cuales el virus B está involucrado en el proceso de la oncogénesis ni la patogénesis del carcinoma hepatocelular y su asociación con el virus B. En el amplio campo de las posibilidades, estudios recientes han sugerido la importancia de la diversidad antigénica del virus $B$ y la relación entre genotipo del virus y patogenicidad, especialmente cuando se asocian cepas del VHB del genotipo $F$ con el virus delta genotipo III (105). Estudios como el recientemente publicado por Blitz y col. (106) demuestran la importancia de investigar los genotipos y subtipos del virus $B$ en las regiones que presenten altas prevalencias de portadores, carcinoma hepatocelular y cirrosis. En poblaciones indígenas de Venezuela, el subtipo adw4 del genotipo $\mathrm{F}$ tuvo una positividad del $97 \%$. El genotipo $\mathrm{F}$ fue, además, el de mayor prevalencia entre las muestras evaluadas.

Las infecciones ocasionadas por los virus $B$ y $D$ presentan una amplia gama de posibilidades de investigación en los diversos campos de la biomedicina. La continua monitorización del comportamiento de los virus B y D en sus aspectos clínicos y biológicos permitirá evaluar el impacto de los programas de prevención a través de la vacunación y desarrollar nuevas estrategias ante los cambios detectados mediante las actividades propias de la vigilancia epidemiológica.

\section{Agradecimientos}

El autor presenta este artículo como un homenaje a la memoria del doctor Bernardo Buitrago, ilustre patólogo del Instituto Nacional de Salud, por sus importantes aportes al conocimiento de la epidemiología, patología y diagnóstico del VHB y muy especialmente del virus delta en Colombia.

Igualmente expresa su reconocimiento al Grupo de Epidemiología del Instituto Nacional de Salud, especialmente a los doctores Mancel Martínez y Fernando de la Hoz, por sus importantes aportes y trabajos sobre la epidemiología de los virus B y D en Coiombia. Agradece, además, a todos los autores por compartir su información en algunos casos aun no publicada.

Expresa también sus agradecimientos a Biolehner por el continuo apoyo y soporte en la preparación y elaboración de este trabajo.

Las opiniones expresadas en este artículo son enteramente responsabilidad del autor y no representan políticas ni opiniones de las autoridades de salud o de instituciones.

\section{Referencias}

1. World Health Organization. Towards the elimination of hepatitis B: a guide to the implementation of national immunization programs in the developing world. October, 7-9, 1991.

2. OMS/OPS/PAI. Vacuna contra la hepatitis B Atacando una pandemia.1994:2-4

3. Hadler SC, Margolis HS. Hepatitis B immunization: vaccine types, efficacy, and indications for immunization. En: Remington JS, Swartz MN, eds. Current Clinical Topics in Infectious Diseases. New York: McGraw Hill 1992; 282-308.

4. Botero RC. Editorial. Hepatitis B. Perspectivas reales de control a corto plazo. Acta Médica Colombiana 1997; 22: 2: 50-55

5. Shapiro CN. Epidemiology of viral hepatitis. Documento CDC, USA.1994.1-12

6. Torres JR. Hepatitis B and hepatitis delta virus infection in South America. Gut 1996; 38 (suplemento 2): S48-S55.

7. Buitrago B. Patología geográfica: Historia de la Hepatitis B y D en Colombia. Biomédica 1991; 11: 1,2,3,4: 5-26.

8. Buitrago B, Popper $\mathbf{H}$ et al. Specific histologic features of Santa Marta hepatitis. A severe form of hepatitis Delta infection in Northern South America. Hepatology 1986; 6:6: 1285-1292. 
9. Buitrago B, Hadler SC et al. Epidemiologic aspects of Santa Marta hepatitis over a 40-year period. Hepatology 1986; 6:6: 1292-1296.

10. Popper $\mathbf{H}$, Buitrago $\mathbf{B}$ et al. Pathology of hepatitis delta infection in the Amazon Basin. In: Rizzetto M, Gerin $\mathrm{JL}$ and Purcell $\mathrm{RH}$. eds: The hepatitis delta virus and its infection. New York, N.Y., Alan R. Liss. 1987: 121.

11. Buitrago B, Martínez M, Hadler SC, Maynard JE, Boshell J, Rossi F, Espinal C. Surveillance of hepatitis delta virus infection in Colombia, South America. In: Gerin JL, Purcell RH and Rizetto M. eds: The hepatitis Delta Virus. New Ycrk, Wiley Liss. 1991: 21-26.

12. WHO. Expanded Program on Immunization: Hepatitis $B$ vaccine. Making global progress. Update, October 1996.

13. Juliao O. Prevalencia de antígeno de superficie de hepatitis B en Colombia. Biomédica 1991; 11:1,2,3,4 56-60.

14. Martínez M, De la Hoz F, Jaramillo LS et al. Seroepidemiología de la infección por el virus de la hepatitis $B$ en niños de la Amazonia Colombiana. Biomédica 1991;11: 1,2,3,4: 43-48.

15. Martínez M, de la $\mathbf{H o z}$ F, Helen T. Epidemiología de la infección por el virus de la hepatitis $B$ en la Amazonia Colombiana. Biomédica 1993; Suplemento No. 1: 161.

16. Buitrago B. Patología geográfica: Historia de la Hepatitis B y D en Colombia. Biomédica 1991; 11: $1,2,3,4: 23$

17. De la Hoz F, Martínez M, Iglesias A et al. Factores de riesgo en la transmisión de la hepatitis B en la Amazonia Colombiana. Biomédica 1992; 12:1: $5-9$

18. Cristancho LM. Prevalencia de Hepatitis B y factores de riesgo asociados en la transmisión del virus en el Departamento del Amazonas. Boletín Epidemiológico. Secretaría de Salud del Amazonas 1995; 25-29.

19. Duque J, Moore P, Suárez J et al. Perfil epidemiológico del departamento del Amazonas. Boletín Epidemiológico.Secretaría de Salud del Amazonas.1996; 9-35.

20. Rivas F, Fino A, Hernández $\mathbf{M}$ et al. Transmisión sexual de hepatitis B en Charras, Guaviare, Colombia. Jornadas Epidemiológicas, Cali, 1994.OPS-INS: 97.

21. Rivas F, Buitrago B, Cárdenas V et al. Brote de hepatitis Delta en Charras, Guaviare, 1994. Boletín Epidemiológico Instituto Nacional de Salud 1995; 3:2: 57-58.
22. Rondón S, Revelo D, de la Hoz F et al. Estudio de prevalencia de la infección por hepatitis $B$ en Puerto Leguizamo, Putumayo. IQCB 1996; 2:14: 155-158.

23. Buitrago B. Patología geográfica: Historia de la Hepatitis B y D en Colombia. Biomédica 1991; 11: 1,2,3,4: 22 .

24. Buitrago B. Patología geográfica: Historia de la Hepatitis B y D en Colombia. Biomédica 1991; 11 : 1,2,3,4: 11 .

25. Sanmiguel AL, Luna OM. Prevalencia de antígeno de superficie de hepatitis $B$ en embarazo y transmisión vertical. Tesis de Grado en Pediatría. Colegio Mayor de Nuestra Señora del Rosario. 1988.

26. Sierra F, Gómez RD, Botero RC et al. Frecuencia de marcadores serológicos del virus $B$ en maternas. REV Col Gastroent 1988; 3: 3: 331.

27. Botero RC, Villegas $\mathbf{N}$, Sierra $\mathbf{F}$ et al. Prevalence of HBV, HCB,HAV and HIV infection in pregnant women in 2 hospitals in Bogotá, Colombia, S.A. Hepatology 1991; 14:4: 200A.

28. Villegas de MN, Botero RC, Ordoñez AM et al. Frecuencia de infección con el virus de la hepatitis $B$ en homosexuales seropositivos y seronegativos para el VIH. Acta Médica Colombiana 1988; 13: 4: 394.

29. Lobo-Guerrero J, Solano MH, García M, Cuellar C. Valoración en hemofílicos del VIH, Hepatitis B (HB) y Hepatitis C (HC). Acta Médica Colombiana 1992; 17: 4: 306.

30. Linares A, Riascos A. Seroconversión a la vacuna de hepatitis $B$ en una población de niños con leucemia. Aprobado para publicación Revista de Enfermedades Infecciosas en Pediatría.

31. Ljunggren KE, Patarroyo M, Engle R et al. Viral hepatitis in Colombia: a study of the "Hepatitis of the Sierra Nevada de Santa Marta". Hepatology 1985 6:2: 299

32. Botero RC, Correa G, Arango C et al. Primera evidencia serológica que el virus de la hepatitis $C$ (HCV) es causa importante de hepatopatía crónica en nuestro País. Acta Med Colomb 1990; 15: 4: 241.

33. Buitrago B. Patología geográfica: Historia de la Hepatitis B y D en Colombia. Biomédica 1991; 11: $1,2,3,4: 23$

34. Cuevas $\mathbf{H}$, Raad J, Neira $M$ et al. Seroepidemiología de la hepatitis B en muestras remitidas al Instituto nacional de Salud por los laboratorios de la Red Nacional durante el primer trimestre de 1996. IQCB 1996; 2: 9: 74-78.

35. Buitrago B. Patología geográfica: Historia de la Hepatitis B y D en Colombia. Biomédica 1991; 11: 1,2,3,4: 11 
36. Rubio LH, González M, Sánchez JF, Velandia MP. Brote de hepatitis B en el municipio de Nariño, Cundinamarca, 1995. IQCB 1995; 8:1: 57-60.

37. Díaz $\mathbf{M J}$ Jaramillo $\mathbf{A C}$, Zúñiga $\mathbf{M}$ et al. Hepatitis en la Vega, Cundinamarca, 1991-1995. Biomédica 1997; 17:2: 240-241.

38. Velandia M, de la Hoz F, Martínez M et al, Prevalencia de hepatitis $B$ en un servicio de ginecobstetricia, 1992-1993. Biomédica 1997; 17:4: 292-298.

39. De la Hoz F, Velandia M, Martínez M et al. Estudio de un brote de hepatitis $B$ en la cárcel de una ciudad intermedia colombiana 1992-1993. Infectio $1995 ; 1: 1: 6-11$.

40. Buitrago B. Patología geográfica: Historia de la Hepatitis B y D en Colombia. Biomédica 1991; 11 : 1,2,3,4: 22

41. Villar LA, Quintero E, Rivera CC. Prevalencia de infección por HIV y virus de hepatitis B,C y D en la población donante de Barrancabermeja (Santander). Biomédica 1993; Suplemento 1: 165.

42. Botero RC, Correa G, Cerón CE et al. Brote intrafamiliar de hepatitis $B$ en una área rural de Antioquia. Sección de Gastroenterología y Hepatología, HUSVP, Universidad de Antioquia. Documento 1983

43. Botero RC, Correa G, Zambrano F et al. Brote de hepatitis $B$ en la vereda Las Hojas, municipio de San Vicente, Antioquia, 1983. Sección de Gastroenterología y Hepatología, HUSVP, Universidad de Antioquia. Documento 1983.

44. Equipo de Salud, Jardín Antioquia. Brote de hepatitis en la comunidad indígena de Cristinía. Boletín Epidemiológico de Antioquia 1987; XI:4: 200201.

45. Ochoa LM. Seroepidemiología de la hepatitis B, Occidente de Antioquia, Colombia 1993. Boletín Epidemiológico de Antioquia 1994; XI:4: 371-380.

46. Ochoa LM. Seroepidemiología de la hepatitis B. Población indígena Embera-Katio. Occidente de Antioquia-Colombia, 1993-1994.

47. Restrepo RE, Sierra ML. Prevalencia de marcadores de hepatitis $\mathrm{B}$ y de algunos factores de riesgo para su transmisión. Veredas Manzanares y Travesías. Támesis, Antioquia 1994. Boletín Epidemiológico de Antioquia 1994; XI:4: 376-380.

48. Zea MV. Prevalencia serológica de marcadores del VHB e identificación de riesgo en Punta Ocaidó Urrao, Antioquia 1993-1994. Boletín Epidemiológico de Antioquia 1994; XI:4: 381-386.

49. Buitrago B. Patología geográfica: Historia de la Hepatitis B y D en Colombia. Biomédica 1991; 11: 1,2,3,4: 13 .
50. Tirado V, Jaramillo C, Ramírez $\mathbf{R}$ et al Vacunación contra la hepatitis B viral (HBV) en personal médico y paramédico del Instituto de Seguros Sociales, Seccional Antioquia, Medellín Colombia. Boletín ISS 1988.

51. Dirección de Epidemiología y Promoción de la Salud. Perfil Epidemiológico de Antioquia 1997. Hepatitis B. Boletín Epidemiológico de Antioquia 1997; XXII:3: 303-304, 369-372.

52. Rojas JH. Hepatoma, cirrosis y hepatitis B en Cali: Una revisión 1987-1996. Secretaría de Salud de Cali. Unidad de Epidemiología 1996.

53. Unidad de Epidemiología. Hepatitis B en el Departamento del Valle del Cauca.1994-1996. Secretaría Departamental de Salud 1997.

54. Arboleda M, Jaramillo C, Echeverry ML et al. Un nuevo foco de hepatitis fulminante aguda por virus Delta: Urabà-Colombia-1987. Informe Preliminar. Boletín Epidemiológico de Antioquia 1987; 33: 339-353.

55. Padilla $\mathrm{J}$, Arriaga A. Hepatitis $A, B$, y $D$ en el Chocó. Biomédica 1997; 17:4: 286-291.

56. Padilla J, Arriaga A, Makanaky G. Seroprevalencia de hepatitis B y factores de riesgo asociados en Riosucio, 1992. Biomédica 1993; Suplemento No 1: 162-163.

57. Fals Borda E, Páez O, Remolina A et al. Análisis clínico epidemiológico de una epidemia de hepatitis en la ciudad de Barranquilla. Salud Uninorte 1986; 3:2: $75-89$

58. Fals Borda E, Páez O, Remolina A et al. Análisis clínico epidemiológico de una epidemia de hepatitis en la ciudad de Barranquilla II. Salud Uninorte 1986 ; 3:3: 161-175.

59. Egea E, Garavito G, Páez $O$ et al. Prevalencia de HBsAg y/u otros marcadores serológicos de HBV en tres comunidades de la costa norte de Colombia. Informe Centro de Investigación y Desarrollo en Inmunología y Biología Molecular, Universidad del Norte 1994

60. Haag A. prevalencia de marcadores serológicos de hepatitis B en grupos de riesgo en Barranquilla. Informe Universidad del Norte 1993

61. Urbina D, Pallares J, Jiménez C. Marcadores serológicos del virus de la hepatitis $B(V H B)$ en personal del Hospital Universitario de Cartagena. Ciencia Tecnología y Educación 1987; 7:1: 27-33.

62. Ospino L. Hepatitis B riesgo y epidemiología. Prevalencia en indígenas municipio de Valledupar. DASALUC 1993.

63. DASALUC. Resultados de pruebas realizadas a unidades de sangre en bancos de sangre en el 
Departamento del Cesar. Boletín Epidemiológico Departamento noviembre 1995.

64. Espinosa G. Infección por hepatitis B en Arhuacos. Boletín Epidemiológico Instituto Nacional de Salud 1995; 3:2: 59-60.

65. Aguilera A, Martínez M, Guzmán M, Groot H et al. Informe epidemiológico del Cerrejón. Informe Interno Instituto Nacional de Salud 1982.

66. Egea E, Garavito G, Páez O, Blanco A et al. Prevalencia de marcadores de infección por VHB, VHA, VHC y coinfección por retrovirus en indígenas Wayuú. Biomédica 1995; Suplemento No 1: 111.

67. Buitrago B. Patología geográfica: Historia de la Hepatitis B y D en Colombia. Biomédica 1991; 11 : $1,2,3,4: 15-16$.

68. Martínez M, Hadler SC, Maynard JE et al. Prevalencia de hepatitis A, B y D en Colombia. encuesta en 4 poblaciones de la zona bananera, Departamento del Magdalena, Colombia. Biomédica 1987; Suplemento No 1: 92.

69. De la Hoz F, Martínez M, Rossi A, Vásquez M. Epidemiología de la infección por el virus de la hepatitis $B$ en el área rural de Ciénaga, Magdalena. IQCB 1996; 2:2: 9-15.

70. De la Hoz F, Martínez M, Rossi A, Vásquez M. Epidemiología y control de la infección por el virus de la hepatitis $B$ en el área rural de Ciénaga, Magdalena. Biomédica 1996; 16: Suplemento 1: 5556.

71. De la Hoz F, Martínez M, Vásquez M, Rossi A et al. Epidemiología de la infección por el virus de la hepatitis B en dos poblaciones del departamento del Magdalena. Biomédica 1991; 11:1,2,3,4: 65-70.

72. Villanueva A, Fraser P, García R, Ospino P. Fulminant hepatitis in the Sierra Nevada: A superinfection of Delta virus on hepatitis B virus. En: Zuckerman AJ editor. Viral Hepatitis and Liver Disease ; Alan R. Liss Inc. 1988: 415-420.

73. Unidad Bancos de Sangre INS. Resultados del tamizaje en bancos de sangre para enfermedades transmitidas por transfusión en Colombia. Instituto Nacional de Salud 1994.

74. Beltrán M, Raad J, Ayala M, Ching R. Tamizaje de enfermedades infecciosas en bancos de sangre, Colombia, 1995. Biomédica 1997; 17:2: 137-142.

75. Ayala M, Beltrán M. Prevalencia de anticuerpos contra el antígeno central de hepatitis B (anti-HBc) en donantes de 11 bancos seccionales de sangre, enero a agosto de 1997. Informe Quincenal Epidemiológico Nacional 1997; 2:24:349-351.

76. Duque E, Aristizabal T. Antígeno de superficie de hepatitis $B$ en donantes de sangre del Hospital Universitario del Valle. Colombia Médica 1984; 15:1: 10.
77. Urbina D, Montalvo J, Peña V. Marcadores serológicos positivos del virus de hepatitis $B$ (VHB). Acta Médica de Cartagena 1989; 1:1: 70-73.

78. De la Hoz F, Martínez M, Velandia M. Estudio de prevalencia del virus de la hepatitis $B$ en indígenas colombianos. Biomédica 1993; Suplemento No 1:161-162.

79. De la Hoz F, Martínez M, Velandia M. Estudio de prevalencia del virus de la hepatitis $B$ en indígenas colombianos. Informe Epidemiología INS 1996.

80. Bernal J, Zea LM, Zambrano CP, Hernández A et al. Enfermedades infecciosas en poblaciones aisladas de Colombia. En: Friedemann N, Arocha J, Bernal J eds: América Negra. Expedición Humana Pontificia Universidad Javeriana 1992; 165-174.

81. Bernal J, Zea LM, Zambrano CP, Hernández A et al. Infección por el virus de la hepatitis B en poblaciones indígenas y comunidades de raza negra. Informe no publicado 1995.

82. Saravia J, Sussman O, Rueda N, Pardo G. Prevalencia de marcadores serológicos y portadores crónicos asintomáticos del virus de la hepatitis B en el Hospital San Juan de Dios. 19861987.

83. Botero RC, casas MC, Sanabria JR et al. Infección por el virus de la hepatitis $B$ en personal médico y paramédico hospitalario. Rev Colom Lab Clín $1986 ; 15: 44: 162$.

84. Juliao O, González A, Ramírez V, Rojas MC et al. Estudio de inmunogenicidad para dos vacunas recombinantes contra hepatitis $\mathrm{B}$ comparando dos esquemas. Biomédica $1991 ; 11: 1,2,3,4: 71-83$.

85. Plata G, Myreya CL, Obregón J, Galviz E. Programa de prevención de hepatitis $B$ en el Hospital Militar Central (Informe preliminar). Acta Médica Colombiana 1992; $17: 4: 109$.

86. Botero RC, Urdaneta $F$, Sirutis D. Seroprevalencia de marcadores de hepatitis B y C en trabajadores del área de la salud. Acta Médica Colombiana $1994 ; 19: 2: 62-75$.

87. Subdirección de Vigilancia Epidemiológica, Secretaría Distrital de Salud. Seroprevalencia de hepatitis B en trabajadores de la Secretaría Distrital de Salud. Informe 1994.

88. Pimiento S, Navarro MC, Botero RC et al. Infecciones por VIH y virus de las hepatitis B y C secundarias a punciones percutáneas y a exposición de mucosas. Resúmenes trabajos científicos VII Congreso Panamericano de Infectología $1995 ; 61$.

89. Fajardo HA, Gómez A. Hepatitis B en trabajadores de la salud, del Hospital San Juan de Dios e Instituto Materno Infantil, Santafé de Bogotá, 1992-1993. 
Revista de la Facultad de Medicina Universidad Nacional de Colombia $1994 ; 42: 3: 127-134$.

90. Jaramillo C, Figueroa A, Rubio A et al. Encuesta sobre conocimientos, actitudes y prácticas de riesgo para la infección por VHB y VHC en personal asistencial del Instituto de los Seguros Sociales (ISS). Tribuna Médica 1996 ; 94 :2 : 99-107.

91. Instituto Nacional de Salud. Prevalencia de infección por hepatitis $\mathrm{B}$ y $\mathrm{C}$ entre trabajadores de la salud de IPS propias y afiliadas al Seguro Social en diez ciudades del país. Informe Quincenal Epidemiológico Nacional 1997 ; 2 :15 : 219-222.

92. Arroyave $\mathrm{ML}$, Echeverry $\mathrm{ML}$, Jaramillo $\mathrm{C}$ et al. Infección por el virus de la hepatitis B (VHB) en el personal de instituciones de salud de MedellínColombia. Medicina UPB $1985 ; 4: 1: 17-29$.

93. Arroyave ML, Arbeláez M. Prevalencia de marcadores de infección del virus de la hepatitis B y seroconversión a la vacuna en trabajadores del Hospital U. Sn. Vicente de Paul. Resúmenes trabajos científicos VII Congreso Panamericano de Infectoloyía $1995 ; 61$.

94. Arroyave A, Díaz J, Ospina S et al. Estudio serológico para marcadores de hepatitis B y vacunación en trabajadores de salud. Antioquia 1993-1994. Boletín Epidemiológico de Antioquia 1994 ; XIX : 4 : 350-363.

95. Serra M, Alzate A, Concha A, Corral R et al. Seroprevalencia de marcadores de hepatitis B en personal de salud. Centro de Investigaciones Epidemiológicas, Facultad de Salud, Universidad del Valle. ARP Seguro Social 1996.

96. Duque E, Aristizabal T, Restrepo RL. Marcadores serológicos de hepatitis B (AgHBS y Anti-HBs) en personas de alto riesgo. Colombia Médica $1988 ; 19: 3: 98$.

97. Haag A. Seroprevalencia regional en trabajadores de la costa Atlántica. Informe CETI DASALUD. 1993.

98. Ortega W, Ospino LF, Padrón CE. Prevalencia y distribución de marcadores de hepatitis $B$ y factores asociados en funcionarios del Hospital Rosario Pumarejo de López y DASALUC, Valledupar, 1994. Informe no publicado.

99. Cuevas H, Bruzón L, Ramírez L et al. Tamizaje prevacunal de la hepatitis $B$ en trabajadores del Hospital de Nazareth y sus centros de influencia en la Alta Guajira. Acta Médica Colombiana 1997 ; $22: 2: 56-60$.

100. Schumis G, Zicker F, Pinheiro F, BrandlingBennett D. Risk for transfusion-transmitted infectious diseases in Central and South America Emerging Infectious Diseases 1998; $4: 1: 5$-11.

101. Gamboa M, González P, Guevara M, Ibarra L. Vacunación contra hepatitis B : Impacto en una población endémica, Julio Zawady, Ciénaga, Magdalena, 1997. Tesis de Grado Especialidad en Epidemiología. Universidad Colegio Mayor de Nuestra Señora del Rosario, Instituto de Ciencias de la Salud, CES.

102. WHO,Expanded Programme on Immunization. Immunization Policy. The expected effect of immunization on disease epidemiology. WHO/EPI/ GEN/95.03 Rev 1 ; 17-20.

103. Zuckerman AJ. Developing new hepatitis B immunisation strategies. Gut 1996 ; 7 :suppl 2 : S60-S62.

104. Melnick JL. Hepatocellular carcinoma caused by hepatitis B virus. En: Evans A. editor. Viral Infections of Humans, third editiun 1989. Plenum Medical Book Company. Chapter 29 ; 769-780.

105. Casey JL, Niro GA, Engle RE et al. Hepatitis B virus (HBV)/hepatitis D virus (HDV) coinfection in outbreaks of acute hepatitis in the Peruvian Amazon Basin: the roles of HDV genotype III and HBV genotype F. J Infect. Dis. 1996 ; 174 : 920-926.

106. Blitz L, Pujol F, Swenson P $e^{+}$ll. Antigenic diversity of hepatitis $B$ virus strains of genotype $F$ in Amerindians and other population groups from Venezuela. Journal of Clinical Microbiology 1998 ; $36: 3: 648-651$. 


\section{FE DE ERRATAS}

Lutzomyia en Bucaramanga

Volumen 18 , número 3

- página 162, segurida columna, tercer párrafo, séptima línea:

dice "36 casos de leishmaniasis cutánea", debe decir "125 casos de leishmaniasis cutánea".

- página 163, la figura 1 no debió haberse impreso; fue reemplazada por el mapa 1 que aparece en la página 165.

- página 163, segunda columna, tercer párrafo, cuarta línea: dice "(figura 1)", debe decir "(mapa 1)". - página 164, segunda línea, primer párrafo: dice "(figura 1)", debe decir "(mapa 1)". 


\section{Instrucciones para los autores}

Biomédica es la revista del Instituto Nacional de Salud. Es una publicación trimestral, eminentemente científica.

Está amparada por la resolución No. 03768 de 1981, emanada del Ministerio de Gobierno.

Ninguna publicación, nacional o foránea, podrá reproducir o traducir sus artículos o resúmenes, sin previa autorización escrita del editor.

Ni la revista, ni el instituto asumen responsabilidad alguna por los puntos de vista expresados por los autores.

La revista no publicará ningún tipo de propaganda comercial. Los nombres de equipos, materiales y productos manufacturados que eventualmente puedan mencionarse, no implican recomendación o propaganda para su uso y sólo se mencionarán como identificación genérica.

1. Biomédica: acepta para publicación artículos, fruto de la investigación, que contribuyan a ampliar los conocimientos sobre biomedicina, realizados tanto en el Instituto Nacional de Salud como en cualquier otro centro de investigación.

2. Biomédica publicará la siguiente categoría de trabajos:

a. Artículos originales: son trabajos inéditos derivados de una investigación biomédica que arroja información nueva sobre aspectos específicos y contribuye de manera relevante al conocimiento y estructuración del movimiento científico del país. Se exceptúan del carácter inédito, aquellos trabajos de investigadores del instituto que hayan sido ya publicados en revistas extranjeras de reconocida prestancia, previo consentimiento escrito del autor y de la respectiva revista.

b. Artículos de investigación básica aplicada: son trabajos de investigación básica que, sin ser originales, utilizan una metodología científica en la confirmación de trabajos previos o introducen modificaciones en procedimientos técnicos.

c. Artículos de investigación clínica: son trabajos de investigación que, utilizando una metodología científica, informan sobre casuística, epidemiología, tratamiento, sistemas diagnósticos, y que pueden ser de interés para el médico en ejercicio.

d. Artículos de laboratorio clínico: son artículos que, utilizando una metodología científica, informan sobre aspectos de laboratorio clínico, tales como: nuevos procedimientos, modificación de técnicas, obtención de valores de referencia para la población colombiana, sensibilidad antimicrobiana, resultado de encuestas serológicas, evaluación de inmunizaciones,etc.

e. Artículos de investigación epidemiológica: son trabajos que, utilizando una metodología científica, dan información sobre problemas de brotes epidémicos, evolución de epidemias, vigilancia y control, y que van más allá de informes susceptibles de publicación en el boletín epidemiológico del instituto.

f. Comunicaciones breves: son trabajos derivados de una investigación básica, epidemiológica o clínica, cuyo conocimiento rápido se considera de gran importancia. 
g. Informes técnicos: son documentos derivados de una reunión de expertos sobre un tema específico.

h. Actualizaciones: son trabajos que, apoyados en bibliografía reciente, destacan los avances más significativos de un problema específico.

i. Memoranda: son documentos muy sobrios que exponen la situación de un aspecto específico.

j. Revisión de temas: son publicaciones densas que revisan exhaustivamente un tema determinado con la más amplia bibliografía posible.

k. Comentarios bibliográficos: son escritos breves, críticos, sobre libros de biomedicina recientemente publicados que, por su impacto, merecen ser comentados.

I. Cartas al editor: son cartas de los lectores solicitando aclaraciones o presentando comentarios sobre material publicado en la revista.

3. Todo material propuesto para publicación será revisado por el Comité Editorial. El editor informará a los autores sobre la recepción de los trabajos y sobre la decisión final que se tome.

4. La revista se reservará el derecho de aceptar o rechazar los artículos y podrá hacer sugerencias que tiendan a mejorar su presentación. Para un mejor cumplimiento de esta función, el Comité Editorial consultará a especialistas en la materia.

5. Los originales de los artículos publicados permanecerán en los archivos de la revista; aquéllos no aceptados, serán devueltos a sus autores.

6. El autor principal recibirá, libre de costo, 5 ejemplares de la revista y 20 separatas de su trabajo.

7. Todo trabajo que se desee publicar en la revista Biomédica deberá ser enviado al editor de la revista, Oficina de Publicaciones, Instituto Nacional de Salud, Avenida Eldorado con carrera 50, zona 6 o Apartado aéreo 80080 y 80334, Santafé de Bogotá, D.C., Colombia.

8. Biomédica sólo considerará para publicación aquellos trabajos que llenen los siguientes requisitos:

a. Ser escritos a máquina, doble espacio, papel tamaño carta, páginas numeradas, dejando un margen de $4 \mathrm{~cm}$ a la izquierda y $2 \mathrm{~cm}$ a la derecha, o en computador llenando las mismas especificaciones y, además, enviando el diskette.

b. Presentar un (1) original y dos (2) copias.

c. El trabajo debe venir organizado así:

- Hoja separada con un título conciso. Puede tener un subtítulo. Autores con nombre, inicial del segundo nombre y apellidos, seguido de un asterisco que indicará al pie de la página, la posición académica, institución, ciudad y país.

- En hoja separada, un resumen en español en donde se enfaticen los aspectos más relevantes del trabajo y que no sea mayor de 250 palabras.

- En hoja separada, un resumen en inglés que tenga el mismo contenido del resumen en español.

- Contenido: introducción, materiales y métodos, resultados, discusión, agradecimientos y bibliografía.

- Las fotografías deben venir en blanco y negro en papel brillante. Biomédica publicará fotografías en colores, cuando a juicio del Comité Editorial, sea necesario. Los cuadros, 
gráficos y figuras deben venir en dibujo en tinta negra o en impresión láser en tamaño proporcional: para una columna, $7,7 \mathrm{~cm}$ de ancho y, para media página, $7,7 \mathrm{~cm} \times 10,3 \mathrm{~cm}$ o página entera, $15,5 \mathrm{~cm} \times 20,5 \mathrm{~cm}$ y, en hoja separada, la leyenda correspondiente.

- La bibliografía debe venir señalada en el texto secuencialmente, con números que correspondan al listado final. Para la correcta transcripción de la bibliografía, Biomédica se acoge a los requisitos unificados para trabajos presentados a revistas biomédicas del Comité Internacional de Editores de Revistas Médicas: Committee of Medical Journal Editors. Uniform requirements for manuscripts submitted to biomedical journals. JAMA 1993; 269:2282-6.

- Deben tenerse en cuenta los siguientes aspectos: en artículos de más de seis autores, se citan sólo los seis primeros autores seguidos de las palabras latina et al., el título completo del artículo, el nombre abreviado de la revista, el año, el volumen, la primera página y el último dígito de la última página.

A manera de ejemplo, citamos:

Goate AM, Haynes AR, Owen MJ, Farrall M, James LA, Lai LY, et al. Predisposing locus for Alzheimer's disease on chromosome 21. Lancet 1989;1:352-5.

Weinstein L, Swartz MN. Pathologic properties of invading microorganism. In: Sodeman WA $\mathrm{Jr}$, Sodeman WA, editors. Pathologic physiology: mechanisms of disease. Philadelphia: Saunders, 1974:457-72.

Renal system (computer program). MSDOS version. Edwardsville (KS): MediSim, 1988. 